\title{
Integrative analysis of neuroblastoma and pheochromocytoma genomics data
}

\author{
Peter M Szabó ${ }^{1}$, Miklós Pintér ${ }^{2}$, Diana Rita Szabó ${ }^{1}$, Adrienn Zsippai ${ }^{1}$, Attila Patócs ${ }^{3}$, András Falus ${ }^{4}$, Károly Rácz \\ and Peter lgaz ${ }^{1 *}$
}

\begin{abstract}
Background: Pheochromocytoma and neuroblastoma are the most common neural crest-derived tumors in adults and children, respectively. We have performed a large-scale in silico analysis of altogether 1784 neuroblastoma and 531 pheochromocytoma samples to establish similarities and differences using analysis of mRNA and microRNA expression, chromosome aberrations and a novel bioinformatics analysis based on cooperative game theory.

Methods: Datasets obtained from Gene Expression Omnibus and ArrayExpress have been subjected to a complex bioinformatics analysis using GeneSpring, Gene Set Enrichment Analysis, Ingenuity Pathway Analysis and own software.

Results: Comparison of neuroblastoma and pheochromocytoma with other tumors revealed the overexpression of genes involved in development of noradrenergic cells. Among these, the significance of paired-like homeobox $2 b$ in pheochromocytoma has not been reported previously. The analysis of similar expression patterns in neuroblastoma and pheochromocytoma revealed the same anti-apoptotic strategies in these tumors. Cancer regulation by stathmin turned out to be the major difference between pheochromocytoma and neuroblastoma. Underexpression of genes involved in neuronal cell-cell interactions was observed in unfavorable neuroblastoma. By the comparison of hypoxiaand Ras-associated pheochromocytoma, we have found that enhanced insulin like growth factor 1 signaling may be responsible for the activation of Src homology 2 domain containing transforming protein 1, the main co-factor of RET. Hypoxia induced factor $1 a$ and vascular endothelial growth factor signaling included the most prominent gene expression changes between von Hippel-Lindau- and multiple endocrine neoplasia type 2A-associated pheochromocytoma.
\end{abstract}

Conclusions: These pathways include previously undescribed pathomechanisms of neuroblastoma and pheochromocytoma and associated gene products may serve as diagnostic markers and therapeutic targets.

Keywords: Pheochromocytoma, Neuroblastoma, Functional genomics, microRNA, Cooperative game theory

\section{Background}

Neuroblastoma (NB) and pheochromocytoma (PCC) are neural crest-derived tumors that are both associated with significant morbidity and mortality.

$\mathrm{NB}$ is the most frequent malignant tumor in children accounting for $15 \%$ of childhood cancer mortality. Approximately $38 \%$ of primary tumors are localized in the adrenal medulla and $1-2 \%$ of newly diagnosed NB cases are related to familial history of disease [1]. The genetic aberration most consistently associated with poor outcome in NB is the amplification of v-myc

\footnotetext{
* Correspondence: igapet@bel2.sote.hu

${ }^{1}$ 2nd Department of Medicine, Faculty of Medicine, Semmelweis University, Szentkirályi str. 46, Budapest H-1088, Hungary

Full list of author information is available at the end of the article
}

myelocytomatosis viral related oncogene $(M Y C N)$, which occurs in $20 \%$ of primary tumors. Chromosomal aberrations as deletion of chromosomes $1 \mathrm{p}, 11 \mathrm{q}$ and gain of $17 \mathrm{q}$ are also associated with poor prognosis. The International Neuroblastoma Staging System is most commonly used for NB staging. Stages 1 and 2 represent localized primary tumors, whereas the primary tumor is unresectable in stage 3 with or without lymph node infiltration, and stage 4 represents any primary tumor with dissemination to distant lymph nodes, bone marrow, liver, skin or other organs. The special $4 \mathrm{~S}$ phenotype is characterized by localized tumor in infants younger than 1 year, with dissemination limited to skin, liver, or bone marrow, and mostly spontaneous regression [1].

\section{Biomed Central}


PCC is a rare tumor, mostly occurring in adults and in the adrenals. Approximately $10 \%$ of PCC are malignant. PCC mostly develops in the adrenal. Extraadrenal PCC is termed paraganglioma (PGL). $25-30 \%$ of all cases are related to monogenic hereditary tumor syndromes including multiple endocrine neoplasia 2 (MEN2), von Hippel-Lindau syndrome (VHL), neurofibromatosis type 1 (NF1) and the group of PGL syndromes caused by mutations in genes encoding succinate dehydrogenase (SDH) subunits and associated factors [2,3]. Novel genes like TMEM127 and MAX have also been described [4,5]. Two major pathogenic pathways have been established in these syndromes: hypoxia pathway (VHL and PGL syndromes) and the pathway involving Ras and mechanistic target of rapamycin (mTOR) activation (MEN2 and NF1). These pathways seem to be implicated in the pathogenesis of sporadic PCC, as well $[5,6]$.

Despite many data on these tumors, we are still far from an overall picture on tumorigenesis. Several studies applying functional genomics approaches have been performed on these tumors to date including the analysis of mRNA and microRNA expression patterns, and studies on chromosome aberrations. In silico analysis of functional genomics studies might be a useful way to decipher common pathogenic pathways and differences [7].

In this study, we have performed a large scale in silico analysis of functional genomics data including a large number of $\mathrm{NB}$ and PCC samples to establish their similarities, differences, and to compare their different subgroups using analysis of gene expression, microRNA expression and their potential mRNA targets, and chromosome aberrations. For this purpose, we have applied GeneSpring, Gene Set Enrichment Analysis (GSEA), and Ingenuity Pathway Analysis (IPA) software. We have also applied a novel bioinformatical analysis based on cooperative game theory for the establishment of relevant gene expression changes. In this approach developed by Moretti et al. [8], genes serve as players and microarray measurements are called cooperative games. By the cooperative game theory analysis we are able to identify the power or relevance index of each gene in inducing the investigated pathological state.

\section{Methods}

\section{Data sets}

Microarray data sets were obtained from publicly available databases (Gene Expression Omnibus (GEO, www. ncbi.nlm.nih.gov/gds) and ArrayExpress (www.ebi.ac.uk/ arrayexpress)). Data on NB were collected from eight studies including 273 samples on three different platforms [9-16]. These were grouped by stages and and MYCN status (Table 1). Data on PCC were collected from three studies $[5,6,17]$ including 330 samples analyzed on four different platforms (Table 2). Samples were grouped by the mutations. In one case [6], the sample set contained malignant PCC, however, due to the

Table 1 Characteristics of the analyzed NB microarray data sets

\begin{tabular}{|c|c|c|c|c|c|}
\hline Study & $\begin{array}{l}\text { Accesion } \\
\text { No. }\end{array}$ & Platform & Samples & Stages & $M Y C N$ \\
\hline $\begin{array}{l}\text { Łastowska } \\
\text { et al., } 2007 \text { [15] }\end{array}$ & $\begin{array}{l}\text { GEO: } \\
\text { GSE13136 }\end{array}$ & $\begin{array}{l}\text { Affymetrix } \\
\text { HG-U133 Plus } \\
\text { 2.0 Array }\end{array}$ & 30 neuroblastoma & $\begin{array}{l}\text { Stage } 1: 4 \text {, Stage } 2: 2, \\
\text { Stage } 3: 1 \text {, Stage } 4: 20 \text {, } \\
\text { Stage } 45: 3\end{array}$ & $\begin{array}{l}\text { MYCN-amplified: } \\
\text { 10, MYC-non-amplified: } 20\end{array}$ \\
\hline $\begin{array}{l}\text { Hiyama et al., } \\
2004 \text { [13] }\end{array}$ & $\begin{array}{l}\text { GEO: } \\
\text { GSE16237 }\end{array}$ & & 51 neuroblastoma & $\begin{array}{l}\text { Stage } 1: 21, \text { Stage } 2: 6, \\
\text { Stage } 3: 5, \text { Stage } 4: 13, \\
\text { Stage } 45: 6\end{array}$ & $\begin{array}{l}\text { MYCN-amplified: 7, } \\
\text { MYC-non-amplified: } 44\end{array}$ \\
\hline $\begin{array}{l}\text { Janoueix- } \\
\text { Lerosey et al., } \\
2008[14]\end{array}$ & $\begin{array}{l}\text { GEO: } \\
\text { GSE12460 }\end{array}$ & & $\begin{array}{l}52 \text { neuroblastoma, } 8 \\
\text { ganglioneuroblastoma, } \\
3 \text { ganglioneuroma, } \\
1 \text { unknown }\end{array}$ & $\begin{array}{l}\text { Stage 1: 10, Stage 2: 10, } \\
\text { Stage 3: } 7, \text { Stage 4: 16, } \\
\text { Stage 4S: } 8 \text {, unknown: } 1\end{array}$ & $\begin{array}{l}\text { MYCN-amplified: 14, } \\
\text { MYC-non-amplified: } \\
\text { 32, unknown: } 6\end{array}$ \\
\hline $\begin{array}{l}\text { Wilzén et al., } \\
2009 \text { [10] }\end{array}$ & $\begin{array}{l}\text { ArrayExpress: } \\
\text { E-MEXP-2250 }\end{array}$ & \multirow{4}{*}{$\begin{array}{l}\text { Affymetrix } \\
\text { HG-U133A } \\
\text { Array }\end{array}$} & 6 neuroblastoma & $\begin{array}{l}\text { Stage 1: 1, Stage 2: } 1 \text {, } \\
\text { Stage 3: } 4\end{array}$ & unknown: 6 \\
\hline $\begin{array}{l}\text { De Preter } \\
\text { et al., } 2006 \\
{[12]}\end{array}$ & $\begin{array}{l}\text { ArrayExpress: } \\
\text { E-MEXP-669 }\end{array}$ & & $\begin{array}{l}18 \text { neuroblastoma, } \\
3 \text { adrenal cortex, } \\
3 \text { adrenal neuroblast }\end{array}$ & $\begin{array}{l}\text { Stage 1: 4, Stage } 3: 3, \\
\text { Stage 4: } 10, \text { Stage } 45: 1\end{array}$ & $\begin{array}{l}\text { MYCN-amplified: } 5 \\
\text { MYCN-non-amplified: } 13\end{array}$ \\
\hline $\begin{array}{l}\text { Albino et al., } \\
2008[11]\end{array}$ & $\begin{array}{l}\text { GEO: } \\
\text { GSE7529 }\end{array}$ & & $\begin{array}{l}10 \text { neuroblastoma, } 3 \\
\text { ganglioneuroblastoma, } \\
6 \text { ganglioneuroma, } \\
9 \text { microdissected tumors }\end{array}$ & unknown: 10 & unknown: 10 \\
\hline $\begin{array}{l}\text { Staege et al., } \\
2004[16]\end{array}$ & $\begin{array}{l}\text { GEO: } \\
\text { GSE1825 }\end{array}$ & & $\begin{array}{l}5 \text { neuroblastoma, } \\
5 \text { Ewing family tumor }\end{array}$ & $\begin{array}{l}\text { Stage } 1: 3, \text { Stage } 3: 1, \\
\text { Stage } 4: 1\end{array}$ & unknown: 5 \\
\hline $\begin{array}{l}\text { Wang et al., } \\
2006[9]\end{array}$ & $\begin{array}{l}\text { GEO: } \\
\text { GSE1825 }\end{array}$ & $\begin{array}{l}\text { Affymetrix } \\
\text { HG-U95 } \\
\text { Version } 2 \\
\text { Array }\end{array}$ & $\begin{array}{l}101 \text { neuroblastoma, } \\
1 \text { fetal brain }\end{array}$ & $\begin{array}{l}\text { Stage 1: } 28, \text { Stage } 3: 23 \text {, } \\
\text { Stage 4: } 50\end{array}$ & $\begin{array}{l}\text { MYCN-amplified: 20, } \\
\text { MYCN-non-amplified: } 81\end{array}$ \\
\hline
\end{tabular}


Table 2 Characteristics of the analyzed PCC microarray data sets

\begin{tabular}{|c|c|c|c|c|}
\hline Study & Accesion No. & Platform & Samples & Mutation \\
\hline $\begin{array}{l}\text { Burnichon } \\
\text { et al., } 2011 \text { [6] }\end{array}$ & $\begin{array}{l}\text { ArrayExpress: } \\
\text { E-MTAB-733 }\end{array}$ & $\begin{array}{l}\text { Affymetrix HG-U133 } \\
\text { Plus } 2.0 \text { Array }\end{array}$ & $\begin{array}{l}188 \\
\text { pheochromocytoma }\end{array}$ & $\begin{array}{l}\text { Sporadic: 95, MEN2A: 9, SDHA: 1, } \\
\text { SDHB: 17, SDHC: 2, SDHD: 3, VHL: } \\
\text { 27, NF1: 9, Other: } 25\end{array}$ \\
\hline $\begin{array}{l}\text { Qin et al., } \\
2010[5]\end{array}$ & GEO: GSE19987 & $\begin{array}{l}\text { Affymetrix HG-U133A } \\
\text { Array }\end{array}$ & $\begin{array}{l}75 \\
\text { pheochromocytoma }\end{array}$ & $\begin{array}{l}\text { Sporadic: 35, MEN2A: 9, SDHB: } 10 \text {, } \\
\text { SDHD: 2, VHL: 6, NF1: 2, Other: } 11\end{array}$ \\
\hline $\begin{array}{l}\text { Qin et al., } \\
2010 \text { [5] }\end{array}$ & GEO: GSE19987 & $\begin{array}{l}\text { Affymetrix HG-U133A } \\
\text { 2.0 Array }\end{array}$ & $\begin{array}{l}50 \\
\text { pheochromocytoma }\end{array}$ & $\begin{array}{l}\text { Sporadic: 36, MEN2A: 3, MEN2B:1, } \\
\text { SDHB: 4, VHL: 3, NF1: 2, Other: } 1\end{array}$ \\
\hline $\begin{array}{l}\text { Hensen et al., } \\
2009 \text { [17] }\end{array}$ & GEO: GSE12921 & $\begin{array}{l}\text { Affymetrix HG-U95 } \\
\text { Version } 2 \text { Array }\end{array}$ & $\begin{array}{l}17 \\
\text { pheochromocytoma }\end{array}$ & Sporadic: 7, SDHD: 6, PGL2: 4 \\
\hline
\end{tabular}

incomplete sample annotation we were unable to identify these. In another case [17], only head-neck PGL samples were investigated that were compared to NB samples. Duplicate samples were removed from the analysis in both $\mathrm{NB}$ and PCC cases. For the taxonomical classification of NB and PCC, we have analyzed 368 random selected samples from 54 different types of endo-, meso- and ectodermic tumors and normal tissues from 17 studies [11,12,18-30] and $39 \mathrm{NB}$ and 75 PCC samples measured on the same Affymetrix HG-U133A Array (Table 3).

Further significant gene sets for $\mathrm{NB}$ and $\mathrm{PCC}$ have been retrieved from studies [31-45], where raw genomic data were unavailable. These studies (10 for NB and 5 for PCC) have been identified by literature search (www. ncbi.nlm.nih.gov/pubmed) and included microarraybased gene expression data from 1511 NB and 201 PCC samples. The list of significant genes was unavailable in

Table 3 Characteristics of the datasets used for cluster analysis

\begin{tabular}{|c|c|c|}
\hline Study & Accesion No. & Samples \\
\hline Henderson et al., 2005 [23] & ArrayExpress: E-MEXP-353 & $\begin{array}{l}4 \text { alveolar rhabdomyosarcoma, } 5 \text { chondroblastoma, } \\
4 \text { chondromyxoid fibroma, } 7 \text { chondrosarcoma, } \\
4 \text { chondroma, } 3 \text { dedifferentiated chondrosarcoma, } \\
3 \text { embryonal rhabdomyosarcoma, } 5 \text { Ewing tumor, } \\
5 \text { fibromatosis, } 8 \text { leiomyosarcoma, } 3 \text { lipoma, } \\
4 \text { malignant peripheral nerve sheath tumor, } \\
10 \text { monophasic synovial sarcoma, } 7 \text { myxoid liposarcoma, } \\
4 \text { neurofibroma, } 11 \text { osteosarcoma, } 3 \text { sarcoma, } \\
4 \text { schwannoma, } 3 \text { well-differentiated liposarcoma }\end{array}$ \\
\hline Giordano et al., 2006 [21] & ArrayExpress: E-GEOD-27155 & $\begin{array}{l}4 \text { anaplastic thyroid carcinoma, } 10 \text { follicular thyroid adenoma, } \\
2 \text { follicular thyroid carcinoma, } 2 \text { medullary thyroid carcinoma, } \\
4 \text { normal thyroid, } 7 \text { oncocytic thyroid adenoma, } \\
8 \text { oncocytic thyroid carcinoma, } 13 \text { papillary thyroid carcinoma }\end{array}$ \\
\hline Freije et al., 2004 [20] & GEO: GSE4412 & $\begin{array}{l}6 \text { astrocytoma, } 10 \text { glioblastoma, } 5 \text { anaplastic mixed } \\
\text { oligo-astrocytoma, } 10 \text { anaplastic oligodendroglioma }\end{array}$ \\
\hline Tirode et al., 2007 [29] & ArrayExpress: E-GEOD-7007 & 11 Ewing tumor \\
\hline Jones et al., 2005 [24] & ArrayExpress: E-GEOD-15641 & $\begin{array}{l}6 \text { chromophobe RCC, } 10 \text { clear cell RCC, } 10 \text { oncocytoma, } \\
10 \text { papillary RCC, } 8 \text { transitional cell carcinoma }\end{array}$ \\
\hline Lenburg et al., 2003 [25] & ArrayExpress: E-GEOD-781 & 16 clear cell RCC, 1 normal kidney \\
\hline De Preter et al., 2006 [12] & ArrayExpress: E-MEXP-669 & 3 adrenal cortex, 3 neuroblast \\
\hline Albino et al., 2008 [11] & GEO: GSE7529 & 3 ganglioneuroblastoma, 6 ganglioneuroma \\
\hline Boyault et al., 2007 [18] & ArrayExpress: E-TABM-36 & 17 hepatocellular carcinoma, 3 hepatocellular adenoma \\
\hline Parent et al., 2008 [27] & ArrayĺExpress: E-GEOD-7142 & 4 hypothalamic hamartoma \\
\hline Wong et al., 2005 [30] & ArrayExpress: E-GEOD-12907 & $\begin{array}{l}5 \text { juvenile pilocytic astrocytoma, } 3 \text { normal cerebellar tissue, } \\
2 \text { normal fetal brain }\end{array}$ \\
\hline Su et al., 2007 [28] & ArrayExpress: E-GEOD-7670 & $\begin{array}{l}1 \text { large cell lung carcinoma, } 14 \text { lung adenocarcinoma, } \\
12 \text { normal lung }\end{array}$ \\
\hline Monzon et al., 2009 [26] & GEO: GSE12630 & 1 medullary thyroid carcinoma \\
\hline Harlin et al., 2009 [22] & ArrayExpress: E-GEOD-12627 & 13 melanoma \\
\hline Salomon et al.,* & ArrayExpress: E-GEOD-4780 & 5 meningioma \\
\hline Corbin et al., 2009 [19] & ArrayExpress: E-TABM-53 & 9 normal kidney, 11 Wilms' tumor \\
\hline Mangiola et al.,* & ArrayExpress: E-GEOD-13276 & 3 normal white matter \\
\hline
\end{tabular}

Asterisks mark studies where references were unavailable. 
the study by Brown et al. [37], and we have therefore calculated it from normalized data by applying SAM (Table 4).

Analysis of raw microRNA expression data was possible in both NB and PCC. MicroRNA data for NB were obtained from the study of Schulte et al. [46] including intensity values of 307 microRNAs in 69 samples. To identify differences in microRNA expression between these groups, one-way ANOVA with Scheffé's post hoc test was used. Statistical analysis was performed by Statistica 8 software (StatSoft Inc., Tulsa, OK, USA). For the analysis of microRNA targets in PCC, we have used our previously published data [47].

Altogether we have analyzed gene expression data from $1784 \mathrm{NB}$ and 531 PCC tissues in our in silico analysis.

\section{Statistical analysis of mRNA profiling studies}

For the classification of tumors, hierarchical clustering was performed on the average of samples within the groups by calculating Euclidean, Squared Euclidean, Manhattan, Differential, Chebyshev distance metric and using the averaged linkage rule. Cluster analysis and all subsequent statistical analyses were performed by Genespring GX 10.5 software (Agilent Tech Inc., Santa Clara, CA, USA).

Identification of gene sets differentially expressed between NB, PCC and other tissues, different stages of NB and different PCC subtypes was carried out by one-way ANOVA. Each ANOVA was followed by Tukey's post hoc test for all pairwise multiple comparisons. Unpaired $t$-test was used for the comparison of $M Y C N$-amplifying, non-amplifying and VHL/SDH-, MEN2/NF1- related

Table 4 Characteristics of gene sets in publications where whole microarray data were unavailable

\begin{tabular}{|c|c|c|}
\hline Study & Number and distribution of samples & Gene list \\
\hline Asgharzadeh et al., 2006 [35] & 102 NB & $\begin{array}{l}55 \text { gene model for the prediction of } \\
\text { high molecular risk NB }\end{array}$ \\
\hline Berwanger et al., 2002 [36] & Stage 1: 19, stage 4: 21 NB & $\begin{array}{l}36 \text { genes differently expressed between } \\
\text { stage } 1 \text { and stage } 4 \text { NB }\end{array}$ \\
\hline Fischer et al., 2010 [40] & $\begin{array}{l}81 \text { unfavorable, } 8 \text { favorable NB, } \\
\text { without } 11 \mathrm{q} \text { aberration }\end{array}$ & $\begin{array}{l}163 \text { genes differently expressed between } \\
\text { favorable and unfavorable NB }\end{array}$ \\
\hline Oberthuer et al., 2006 [42] & $\begin{array}{l}251 \text { NB, among these } 77 \text { was used } \\
\text { to construction of } \\
\text { a gene expression-based classifier } \\
\text { and } 177 \text { to validate it }\end{array}$ & $\begin{array}{l}60 \text { genes with higher than } 2 \text {-fold expression } \\
\text { changes from } 144 \text { gene predictor of } \\
\text { favorable and unfavorable NB }\end{array}$ \\
\hline Oberthuer et al., 2007 [33] & 79 favorable and 48 unfavorable NB & $\begin{array}{l}5 \text { genes with higher than 2-fold expression } \\
\text { changes from } 349 \text { gene predictor of } \\
\text { favorable and unfavorable NB }\end{array}$ \\
\hline Ohira et al., 2005 [34] & $136 \mathrm{NB}$ & $\begin{array}{l}41 \text { top-ranked genes used for prediction of } \\
2 \text { year and } 5 \text { year prognosis of NB }\end{array}$ \\
\hline \multirow[t]{3}{*}{ Schramm et al., 2005 [31] } & $\begin{array}{l}59 \text { MYCN-non-amplified, } \\
9 \text { MYCN-amplified NB }\end{array}$ & $\begin{array}{l}28 \text { top-ranked genes to discriminate } \\
\text { MYCN-non-amplified and MYCN-amplified NB }\end{array}$ \\
\hline & $\begin{array}{l}\text { Stage } 1: 20 \text {, stage } 2: 16 \text {, stage } 3: 7, \\
\text { stage } 4: 15 \text {, stage } 4 S: 10 \mathrm{NB}\end{array}$ & $\begin{array}{l}30 \text { top-ranked genes to discriminate } \\
\text { stage } 1-2 \text { and stage } 3-4 \text { NB }\end{array}$ \\
\hline & & $\begin{array}{l}22 \text { top-ranked genes to discriminate } \\
\text { stage } 4 S \text { and stage } 4 \text { NB }\end{array}$ \\
\hline Takita et al., 2004 [43] & $\begin{array}{l}\text { stage } 1: 9, \text { stage } 2: 4 \text {, stage } 4: 6 \text {, } \\
\text { stage } 45: 1 \mathrm{NB}\end{array}$ & $\begin{array}{l}60 \text { top-ranked genes to discriminate } \\
\text { stage } 1-2 \text { and stage } 4 \text { NB }\end{array}$ \\
\hline Thorell et al., 2009 [44] & 16 favorable and 15 unfavorable NB & $\begin{array}{l}81 \text { genes differently expressed between } \\
\text { favorable and unfavorable NB, } \\
\text { validated by QRT-PCR }\end{array}$ \\
\hline Vermeulen et al., 2009 [45] & 579 NB & 59 prognostic genes for high risk NB \\
\hline Brown et al., 2008 [37] & 12 MEN2A, 11 VHL PCC & $\begin{array}{l}17 \text { genes differently expressed between } \\
\text { MEN2A and VHL by SAM (fold change: } \\
\text { 2-fold, delta lower than 0.05) }\end{array}$ \\
\hline Eisenhofer et al., 2004 [38] & 7 MEN2A, 12 VHL PCC & $\begin{array}{l}493 \text { genes differently expressed between } \\
\text { MEN2A and VHL PCC }\end{array}$ \\
\hline Eisenhofer et al., 2008 [39] & 32 MEN2A, 47 VHL PCC & $\begin{array}{l}42 \text { selected pathway components differently } \\
\text { expressed between MEN2A and VHL PCC }\end{array}$ \\
\hline Huynh et al., 2006 [41] & 13 MEN2A, 18 VHL PCC & $\begin{array}{l}15 \text { genes selected differently expressed genes } \\
\text { between MEN2A and VHL PCC }\end{array}$ \\
\hline López-Jiménez et al., 2010 [32] & $\begin{array}{l}8 \mathrm{SDHB}, 1 \mathrm{SDHC}, 4 \mathrm{SDHD}, \\
15 \mathrm{VHL}, 17 \mathrm{RET}, 4 \mathrm{NF} 1\end{array}$ & $\begin{array}{l}444 \text { genes differently expressed between } \\
\text { VHL/SDH and RET/NF1 PCC }\end{array}$ \\
\hline
\end{tabular}


PCC. Fold change filter was set to 2-fold in each comparison. Furthermore, Benjamini-Hochberg multiple testing correction (corrected $\mathrm{p}<0.05$ ) was performed to minimize false positive cases.

\section{Search for similarities between NB and PCC mRNA expression patterns}

To identify genes with highly similar expression levels between NB and PCC samples, we have used the criteria established by Cheng et al. [48] for the identification of reference genes: i., raw intensity value is higher than 20 percent in at least $80 \%$ of samples in each group. ii., coefficient of variation is lower than 0.3 , and iii. fold change is lower than 1.2. Genes previously identified by Cheng et al. [48] as reference (housekeeping) genes in 4804 samples from 13 different tissues including normal and tumor samples have been filtered out from gene lists. The remaining genes were loaded into Ingenuity Pathway Analysis (IPA). The reference gene selection was performed by an own software written in Java program language.

\section{Cooperative game theory-based analysis of microarray studies}

The main goal of cooperative game theory analysis on microarray samples is the investigation of gene involvement in disease pathogenesis based on a mathematical model. In this analysis, it is initially hypothesized that all genes with more than two-fold expression changes between an investigated sample and the reference sample set play equal role in the pathogenesis, as their cooperation results in a different status. Next, the most frequently involved (playing) genes are searched for. By this approach we are able to identify the most relevant genes (players) in the pathogenesis, because the calculated subsets of genes usually act (change their expression) cooperatively [8].

To calculate the relevance index of genes we have used the same procedure as Albino et al. [11]. We have generated Boolean matrices where the columns represented the samples (games) and the rows represented the genes (players). The values of the matrices were set to 1 if the expression of the gene in the given sample was higher than 2-fold compared to the other group and 0 if not. Shapley values [49] for each gene were calculated as we divided each value in the columns of the Boolean matrices by the sum of the given column and averaged these values by the rows. Finally, each Shapley value was divided by the highest one. We performed these calculations vice versa between the compared groups and genes with values higher than 0.6 in both calculations were selected for further analysis. Gene sets generated by this approach were loaded into IPA. Calculations were performed by an own program written in Java program language.

\section{Gene set enrichment analysis (GSEA)}

GSEA analyzes gene expression data and determines whether a particular set of genes is over- or underrepresented in the samples compared [50]. GSEA was performed by GSEA software v2.0 (www.broad.mit.edu) in pairwise comparisons of NB versus PCC, different stages of NB, $M Y C N$-non-amplifying vs. $M Y C N$-amplifying NB, SDH/VHL vs. MEN2/NF1 PCC and MEN2A vs. VHLassociated PCC. Gene expression results derived from microarray experiments were correlated with chromosomal data and microRNA gene sets. GSEA was performed using gene set permutation type as default and the number of permutation was set to 1000 . Statistical significance levels were defined as nominal p-value 0.05 and false discovery rate 0.25 .

\section{Correlation of GSEA results retrieved from publicly available microarray data with cytogenetic changes}

To correlate gene expression changes to chromosomal aberrations we have compared significantly enriched chromosomal gene sets by GSEA with the list of previously published chromosomal aberrations for the given tumor types. From the gene lists of these overlapping chromosomal regions, we have selected the most prominent expression changes by Leading Edge Analysis (LEA) using GSEA software v2.0 (www.broad.mit.edu). The leading edge subset of genes can be defined as the core accounting for the enrichment signal of the significant chromosomal gene set. This method has been described in our previous study [7] and defined strict cut-off parameters to identify genes harbored on aberrant chromosome regions showing the most prominent expression changes [51].

\section{Correlation of GSEA results retrieved from publicly available microarray data with microRNA expression} Identification of predicted microRNA targets was performed using TargetScan 5.2 (www.targetscan.org), PicTar (http://pictar.org) and MicroCosm Targets (www.ebi. ac.uk/enright-srv/microcosm/htdocs/targets/v5/) databases. The outputs from these databases were merged by an own program written in $\mathrm{C}++$ program language.

Further analysis aimed at tissue specific microRNA target prediction has been performed as described in our previous study [52]. Briefly, unexpressed mRNAs (intensity value is lower than 20 percentile in at least 20 percent of the samples in both groups) were filtered out from target lists. For all significantly differentially expressed microRNAs within the two groups, we have generated gene sets from their expressed target genes. Then GSEA was performed and LEA was used to select 
potential mRNA targets with inverse expression alterations as their regulatory microRNAs. Pairwise comparison was performed between different stages and $M Y C N$-non-amplifying and amplifying NB and between SDH/VHL- and MEN2/NF1- and MEN2A-, VHLrelated PCC. All analyses were performed by own programs written in Java program language.

\section{Pathway analysis}

We have used Ingenuity Pathway Analysis (IPA) to decipher the possible biological relevance of gene expression changes established. (Ingenuity Systems, www. ingenuity.com; Redwood City, CA, USA). Gene sets established both by in silico analysis of mRNA expression (significant expression changes, unchanged expression, results of cooperative game theory analysis and data collected by literature search), GSEA of microRNA and comparative genomic hybridization $(\mathrm{CGH})$ gene sets were subjected to IPA and significant pathways $(\mathrm{p}<0.05)$ were compared to each other.

\section{Results}

We have performed several analyses including a taxonomical analysis based on the gene expression profile of NB and PCC samples and other tissues, and tried to characterize the most prominent differences between neural crest-derived tumors and other tissues. We have compared NB and PCC data to establish their differences and similarities, moreover within the NB and PCC groups, data from different NB stages and from PCC subgroups, respectively, have been analyzed (Additional file 1).

\section{Differences between NB, PCC and other tumors and similarities of NB and PCC tissues}

To categorize NB and PCC among different endo-, meso-, and ectodermic tumors, unsupervised hierarchical clustering was performed on 54 different groups of normal tissues and tumors. By this approach, NB and PCC were clustered close to each other underlining their similarity in gene expression patterns (Figure 1).

By the comparison of NB or PCC groups with the investigated 54 normal tissues and tumor types, we have identified 36 genes significantly differentially expressed in more than $80 \%$ of comparisons (Additional file 2). By the manual inspection of these 36 genes, they could be clearly categorized as genes involved in catecholamine synthesis, transport and storage: dopamine betahydroxylase $(D B H)$, tyrosine hydroxylase $(T H)$, chromogranin A (CHGA), chromogranin B (CHGB), solute carrier family 6 member 2 (SLC6A2), solute carrier family 18 member 1 (SLC18A1), and transcription factors and homeobox genes involved in neural crest-derived cell development: paired-like homeobox $2 \mathrm{a}$ and $2 \mathrm{~b}$ (PHOX2A,
PHOX2B), GATA binding protein 2 and 3 (GATA2, GATA3), heart and neural crest derivatives expressed 2 (HAND2).

To identify genes responsible for the similarities of NB and PCC gene expression patterns, we have searched for genes expressed in both tumors with the lowest fold change and variation. The previously published [48] reference (or housekeeping) genes were filtered out from these gene lists to select genes with unchanged expression specifically between NB and PCC. The analysis was performed on three different platforms. By this approach we have identified 62 genes that were common in at least two comparisons (Additional file 3). By IPA of these gene sets, death receptor signaling was the most significant common pathway in each comparison.

\section{Differences between NB and PCC tissues}

The comparison of NB and PCC was possible on three platforms, and by the comparison of these gene lists we have identified 758 common expression changes in at least two comparisons (Additional file 4), for example: anaplastic lymphoma receptor tyrosine kinase $(A L K)$, neurotrophic tyrosine kinase, receptor, type 3 (NTRK3), tubulin, beta 2A-C, 3 (TUBB2A, TUBB2B, TUBB2C, TUBB3). By IPA, cancer regulation by stathmin1 has been identified as the most significant pathway between PCC and NB.

\section{Expression changes between different subgroups of NB}

The comparison of significant gene lists between stages 1 and 4 was possible on three different platforms. Within these, we have found 28 common expression changes in at least two studies (Additional file 5). The comparison of stage $4 \mathrm{~S}$ and stage $4 \mathrm{NB}$ was possible on one platform. The list of significantly differentially expressed genes was compared to the gene list reported by Schramm et al. [31] and 5 common genes have been found in both, for example: aldehyde dehydrogenase 3 family member A2 (ALDH3A2) and phosphoinositide-3kinase regulatory subunit 1 (PIK3R1) (Additional file 5).

The analysis of gene expression profiles of $M Y C N-$ non-amplifying and $M Y C N$-amplifying NB was possible on three platforms. The comparison of these revealed 259 common significant expression changes in at least two studies. To identify the most reliable expression changes, we intersected this gene set with a further one, reported by Schramm et al. [31]. By this approach, we have identified nine genes with significant expression changes that were common in all four gene sets, for example: DEAD box polypeptide 1 (DDX1), MYCN, ornithine decarboxylase 1 (ODC1), transketolase (TKT) (Additional file 5).

By the comparison of gene lists revealed from the statistical analysis of early versus late stage, $M Y C N$-non- 


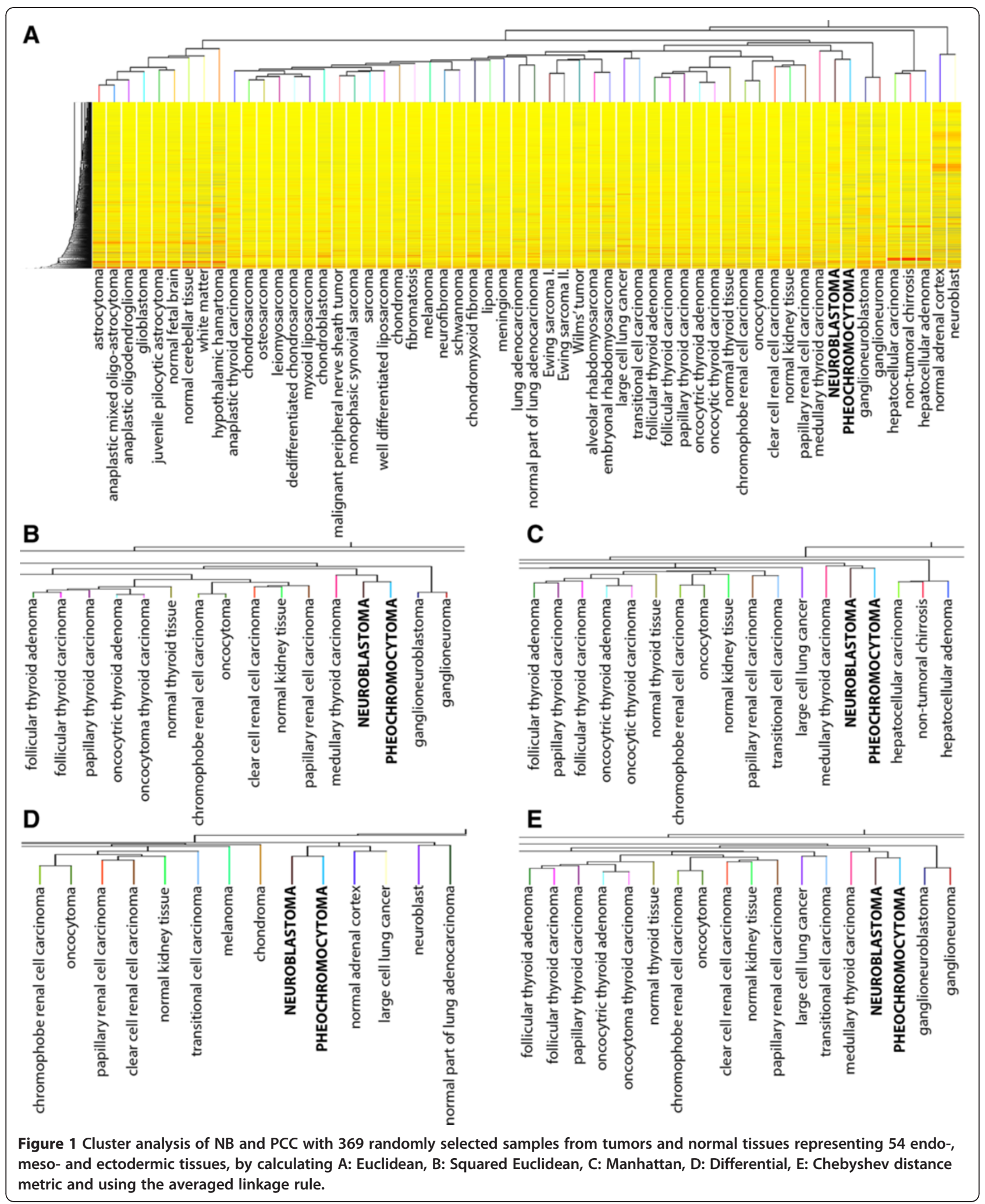


amplifying versus $M Y C N$-amplifying and favorable versus unfavorable NB samples and from the literature search, we have found 519 genes that were reported at least twice in these gene lists (Additional file 5). Among these, the most prevalent genes were: NTRK1, MYCN, secretogranin II (SCG2), pleiotrophin (PTN), neuronal cell adhesion molecule (NRCAM) and ODC1. The IPA of significant gene expression changes, cooperative game theory analysis, chromosomal changes and microRNA affected genes revealed the axonal guidance as the most significant pathway in the pathogenesis of unfavorable NB.

\section{Significant expression changes between VHL/SDH and MEN2/NF1 PCC}

The comparison of VHL/SDH- and MEN2/NF1-associated PCC was possible on three platforms. To generate a more reliable dataset of significant expression changes, we supplemented these gene lists with a further one, found by literature search [32]. By this approach, we have identified 240 common significant gene expression changes in at least two gene lists (Additional file 6), and among these 9 were common in all four comparisons, for example: phenylethanolamine $\mathrm{N}$-methyltransferase (PNMT), ret proto-oncogene (RET), Src homology 2 domain containing transforming protein 1 (SHC1). By IPA,
IGF1 (insulin-like growth factor 1) signaling turned out to be the most significantly influenced pathogenic pathway between SDH/VHL and MEN2/NF1 PCC.

\section{Significant expression changes between MEN2A and VHL PCC}

The comparison of MEN2A- and VHL-associated PCC was possible on three platforms, and a further dataset was analyzed by SAM (significance analysis of microarrays), moreover three significant gene lists were collected from literature search. By the comparison of these seven gene lists, we have identified 162 genes which were common in at least two gene lists, for example: $C H G B$, neural cell adhesion molecule 1 (NCAM1), placental growth factor $(P G F), P N M T$, vascular endothelial growth factor (VEGF) (Additional file 7). By the IPA of significant gene expression changes, cooperative game theory analysis, chromosomal aberrations and microRNA affected genes, the most significant pathogenic pathway was VEGF and hypoxia inducible factor 1 alpha (HIF1- $\alpha$ ) signaling.

\section{Cooperative game theory analysis}

The number of index genes revealed from cooperative game theory analysis [8] was similar to the number of

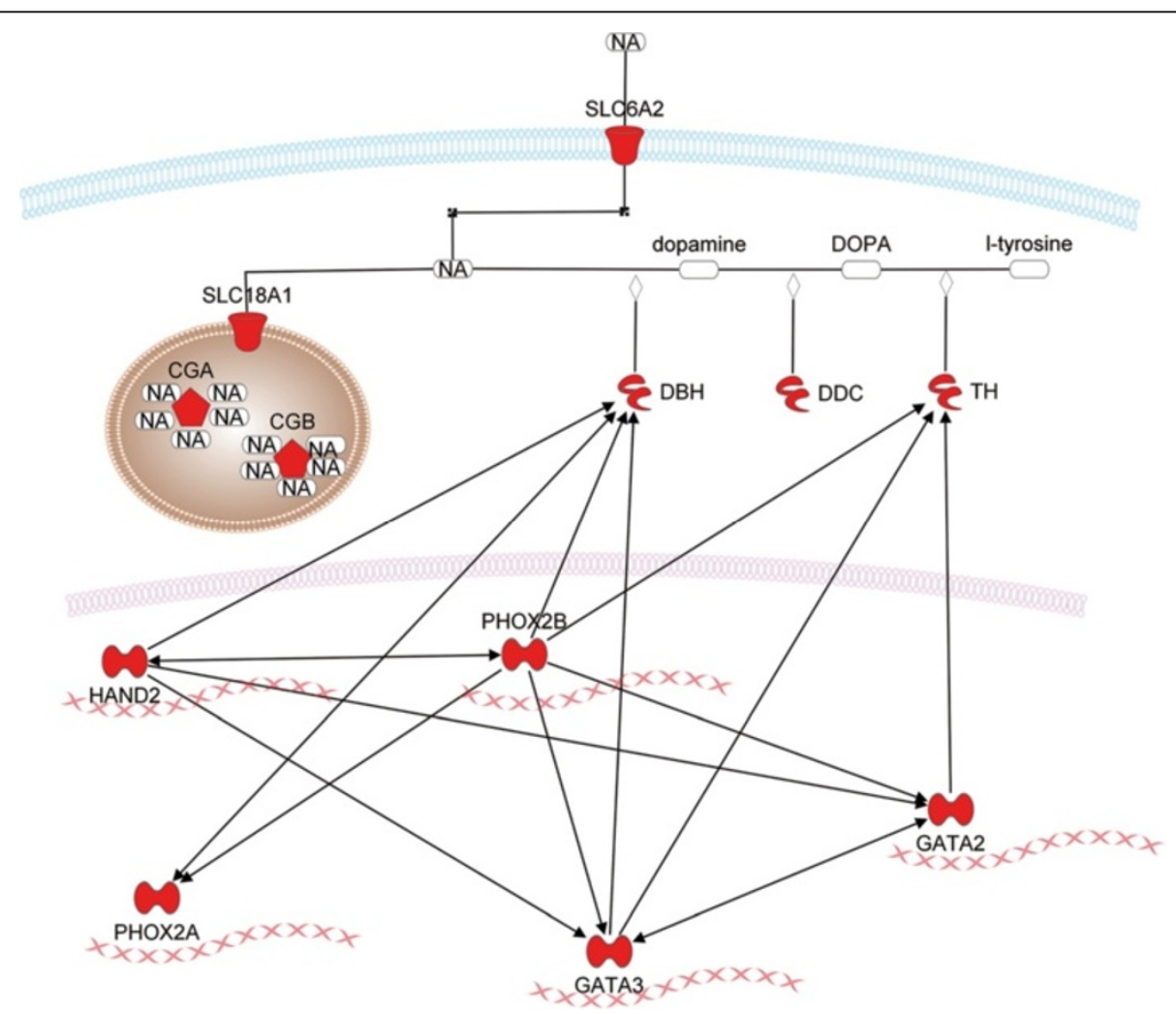

Figure 2 Pathways with altered gene expression patterns involved in the regulation, synthesis, transport and storage of noradrenalin in NB and PCC. Red labeled genes were overexpressed in more than 50 cases between these two entities and other tumors. 
significant gene expression changes and showed good overlap with them. In average, more than $40 \%$ of significant gene expression changes were identified as index genes by cooperative game theory analysis in different comparisons. The pathway analysis of index genes always revealed the same canonical pathways as significant gene lists and supplemented these with several new members. These observations support the applicability of cooperative game theory in the in silico analysis of gene expression.

\section{Discussion}

\section{Comparison of NB and PCC with other tumors}

By the cluster analysis of different tumors and normal tissues, we have found that NB and PCC tissues are more similar to each other than to any other tumor entity. This observation is not surprising, as both NB and PCC are neural crest-derived tumors (Figure 1).

By the inspection of gene expression changes between $\mathrm{NB}, \mathrm{PCC}$ and normal tissues and other tumors, the most characteristic gene expression feature of NB-PCC has been clearly related to the noradrenalin (NA) biosynthesis and neural crest cell development (Figure 2). NA is synthesized in both NB and PCC tissues, and several members of this synthetic pathway have been reported previously in NB as top scoring classifiers $[9,33,34]$. The significance of this pathway is well characterized in NB [10], however, the expression of several of its key members have not been reported in PCC, yet.

The homeobox transcription factor PHOX2B is essential for the differentiation and maintenance of noradrenergic neurons [53]. $P H O X 2 B$ mutations are observed in rare hereditary forms of NB and Hirschsprung's disease [54]. PHOX2B is involved in the transcriptional regulation of RET expression [55], however mutations of PHOX2B in hereditary and sporadic PCC have not been reported, yet.

The downstream targets of the master regulators of neural crest-derived precursor cell development PHOX2B and HAND2 are PHOX2A, GATA2, GATA3. These transcription factors play important roles in the expressional regulation of the $T H$ and $D B H$ genes [56].

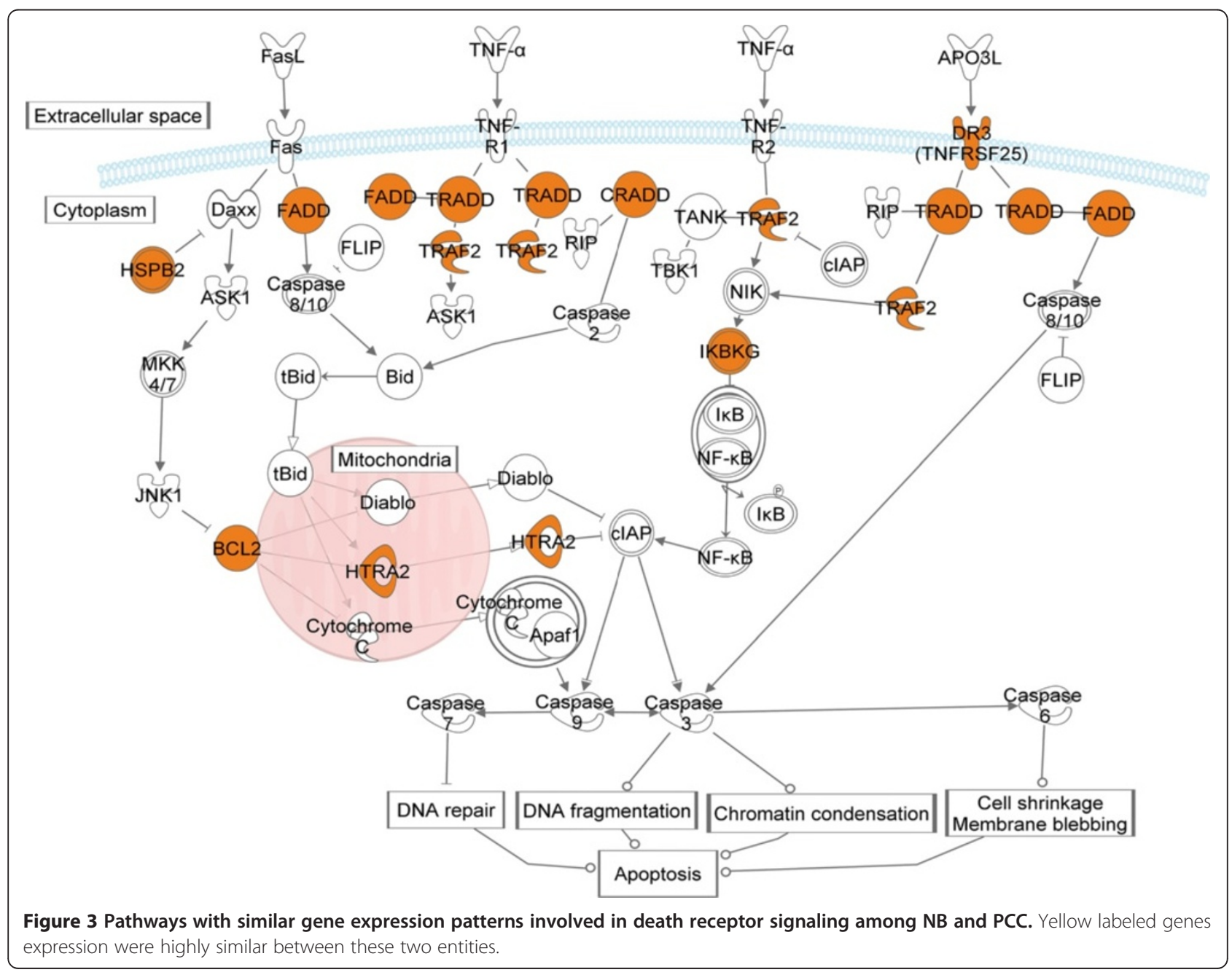


$\mathrm{TH}$ catalyzes the rate limiting step of NA production, and DBH converts dopamine to NA. NA in chromaffin cells is co-stored in secretory granules with CGA and CGB molecules. The uptake into granules is mediated by SLC18A1 protein from the cytoplasm and by SLC6A2 from the extracellular space [10].

By the comparison of NB or PCC tissues with other tumors and normal tissues, we have found the significant overexpression of all the above mentioned genes in NB or PCC samples in more than 90 comparisons. This observation highlights the common origin of $\mathrm{NB}$ and PCC, however, it is surprising that there are only very few data on the expression of these genes in PCC.

\section{Similarities between NB and PCC}

To investigate the most significant similarities between NB and PCC tissues, we have searched for previously unreported reference genes. By this approach, the most similar pathway between NB and PCC was death receptor signaling (Figure 3).

Avoidance of apoptosis is a key process of tumorigenesis. Since this pathway included the most similar gene expression patterns in NB and $\mathrm{PCC}$, we may conclude that these tumors may use the same strategies for rescue from programmed cell death.

The importance of proteins involved in the regulation of apoptosis triggered by death receptors (DRs) has been

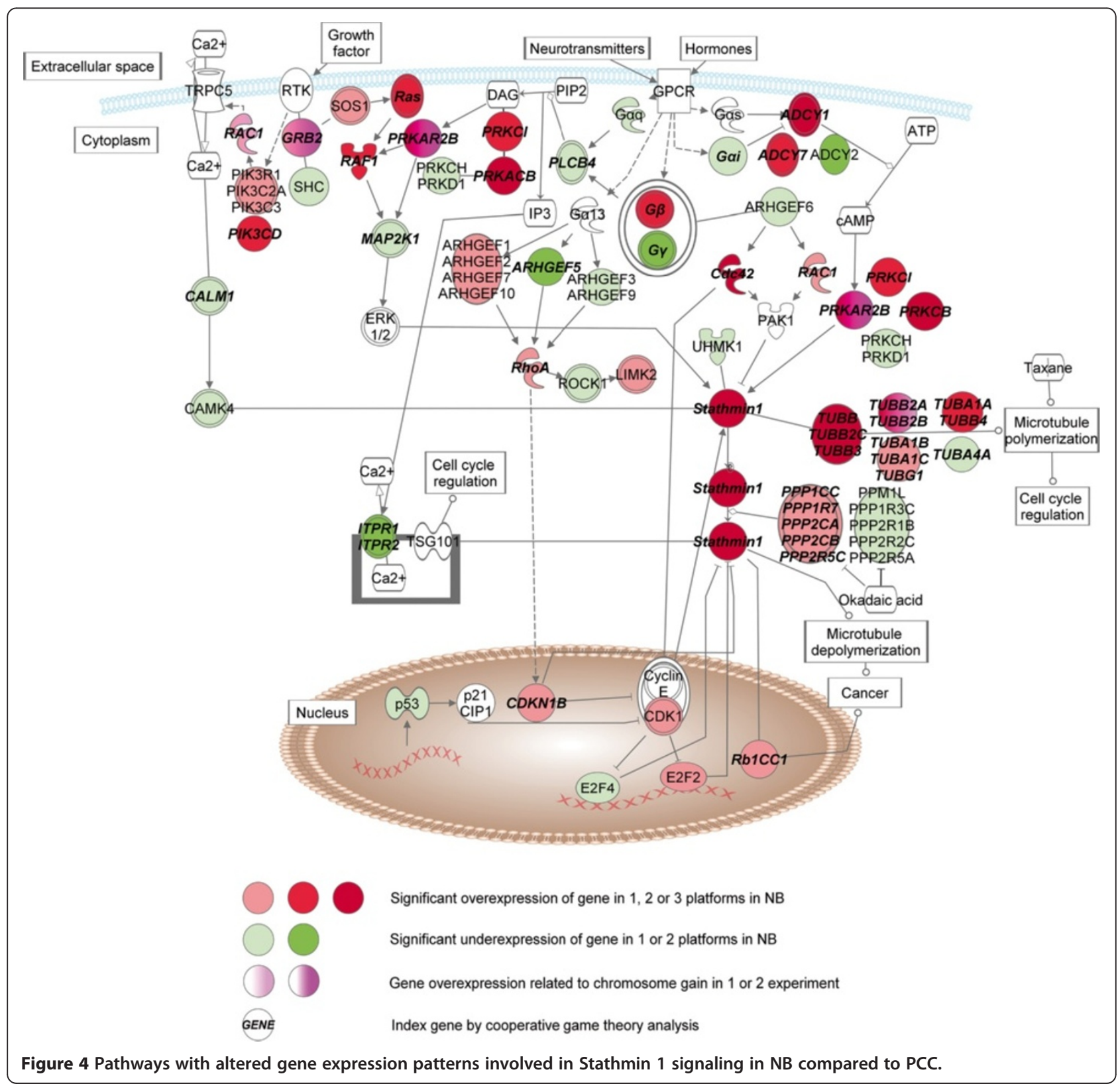


already reported in NB. Apoptosis in mammalian cells can be initiated through two major pathways: one involving tumor necrosis factor alpha (TNF $\alpha$ ) and DR1-6, the other involving release of cytochrome $c$ from mitochondria through Fas activation [57].

Numerous reports underline the significance of mitochondria-dependent signaling in NB. Fas resistance in NB may develop by the inactivation of caspase 8 , which is absent in more than one third of NB cases [58], and often methylated in more than $60 \%$ of PCC [57]. Fas resistance may even develop in caspase 8-expressing NB via high level expression of the antiapoptotic protein BCL2 [58]. In the rat pheochromocytoma PC12 cell line, $B C L 2$ overexpression inhibits apoptosis [59]. We have found very similar expression levels of $B C L 2$ in the investigated NB and PCC tissues. Further members of mitochondria-dependent signaling were also similar between NB and PCC including Fas-associated via death domain $(F A D D)$, HtrA serine peptidase 2 (HTRA2), heat shock $27 \mathrm{kDa}$ protein 2 (HSPB2). These similarities raise the possible involvement of BCL2-mediated Fas resistance and mitochondria-dependent apoptotic pathway in PCCs pathogenesis, as well.
Underexpression of death receptor 3 (TNFRSF15) in NB has been reported previously, and correlated with the frequent deletion of chromosome region 1p36 [60] which chromosomal aberration is also known in sporadic and MEN2A-associated PCC [61]. The expression of DR3 has been very similar in NB and PCC in our analysis.

\section{Differences of NB and PCC}

Cancer regulation by Stathmin 1 (Figure 4) turned out to be the most significantly differentially affected pathway between NB and PCC. Stathmin 1 (STMN1) is overexpressed in a broad range of malignances [62]. Its expression is higher in benign PCC than normal adrenal medulla, and higher in malignant then benign PCC [63]. Stathmin 1 is involved in the regulation of microtubule dynamics by promoting depolymerization of microtubules and preventing polymerization of tubulin heterodimers. Both activities are regulated by mitogen-activated protein kinase (MAPK)-, calmodulin-dependent protein kinase (CAMK)-, p21 protein activated kinase 1 (PAK1)and protein kinase A (PRKA)-mediated phosphorylation, which inactivate stathmin 1 , and thereby prevent its

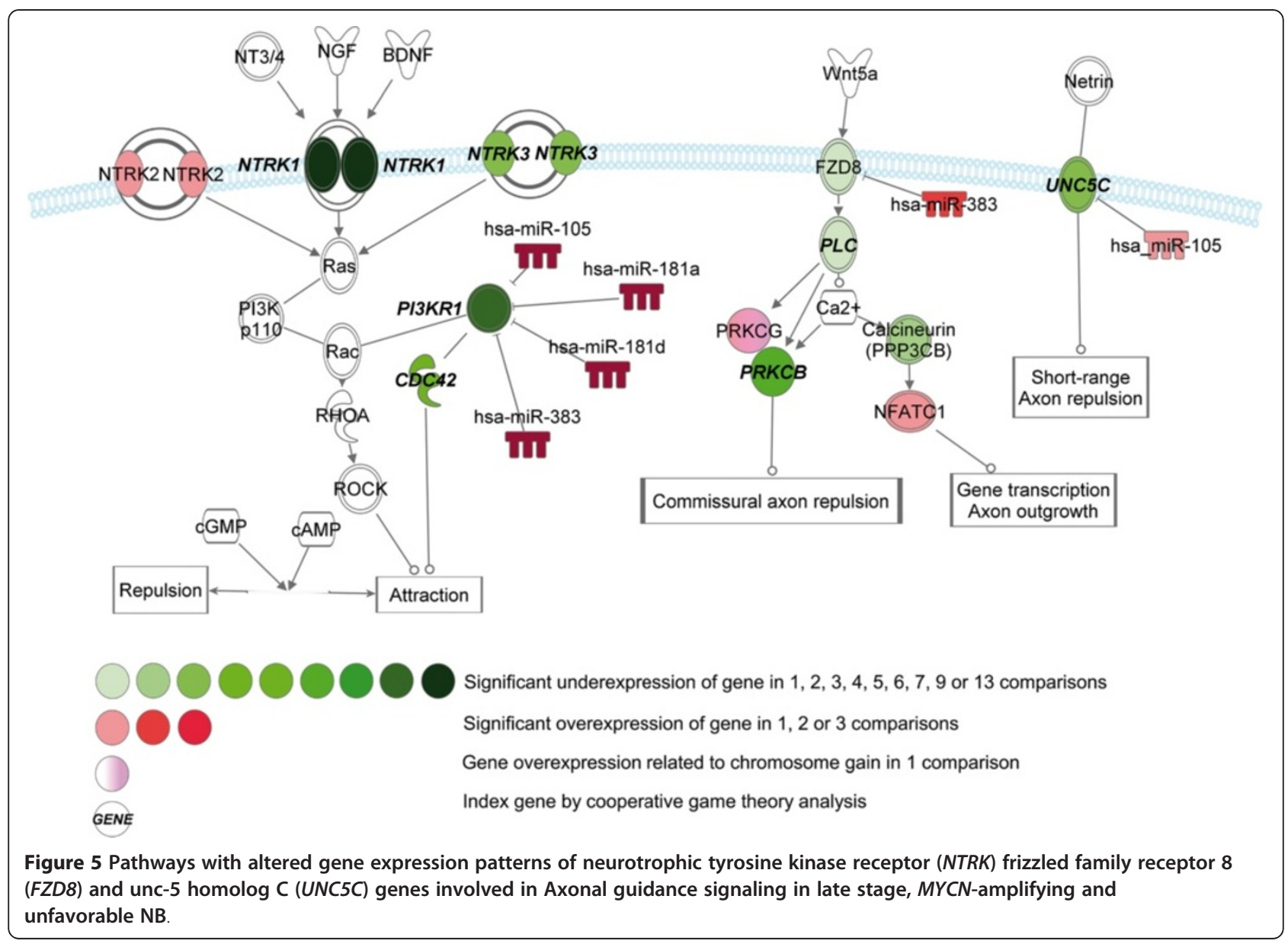


binding to tubulin and interfere with the sensitivity of cancer cells to anti-microtubule drugs [64].

Phosphorylation of stathmin 1 at the beginning of mitosis is pivotal for allowing microtubules to polymerize and assemble into a mitotic spindle, whereas its dephosphorylation by protein phosphatases (PPIs) is critical for cells to exit mitosis. A similar effect is also shown by taxanes and vinca alkaloids, used for the chemotherapy of several cancers including NB [65].

By the comparison of NB and PCC, we have observed mainly the overexpression of genes involved in stathmin phosphorylation and dephosphorylation, tubulins and stathmin 1 in NB. These changes may highlight important differences in cell cycle regulation and chemoresistance between benign PCC and malignant NB via the enhanced regulation of stathmin function.

\section{Differences between early, late stage, MYCN-amplifying, non-amplifying NB}

Within the NB group, we have focused on the comparison of early and late stages, $M Y C N$-non-amplifying and amplifying, and unfavorable and favorable NB. By this approach, we have observed the underexpression of axonal guidance pathway members in late stage, $M Y C N$ amplifying and unfavorable NB (Figures 5, 6, 7).

Neuronal connections are formed by migrating axons, and the growth edge contains receptors which help to navigate the axon to its final destination. Several attractive and repulsive guidance cues and receptors have been identified for example roundabout 1 (ROBO1), plexin, neurophilin, ephrin (EFN) and neurotrophic tyrosine kinase (NTRK) receptors [66].

Among the receptors involved in axonal guidance, the underexpression of NTRK1 (TrkA) was the most common (observed in more than ten datasets) alteration in $M Y C N$-amplifying and unfavorable NB (Figure 5). We have also observed the underexpression of NTRK3 $(\operatorname{TrkC})$ in three cases and the overexpression of NTRK2 (TrkB) in one. High NTRK1 and NTRK3 and low NTRK2 expression in NB was associated with favorable clinical features and inversely associated with $M Y C N$ amplification [67]. Among downstream members of NTRK signaling, we have also observed the underexpression of PIK3R1 in eight, PIK3C3 in two, PLCB1 and PLCD4 in 1-1 dataset in late stage, $M Y C N$-amplifying and unfavorable NB. The underexpression of PIK3R1 was correlated with the overexpression of microRNAs $h s a-m i R-105$, hsa-miR-181a, hsa-miR-181d and hsa-miR-383 in these cases and it was a very frequent expression change in our in silico analysis, however, its significance in NB pathogenesis has not been described yet.

Significant expressional alterations of other receptors involved in neuronal migration were also observed. Underexpression of plexin receptor C1 (PLXNC1), a

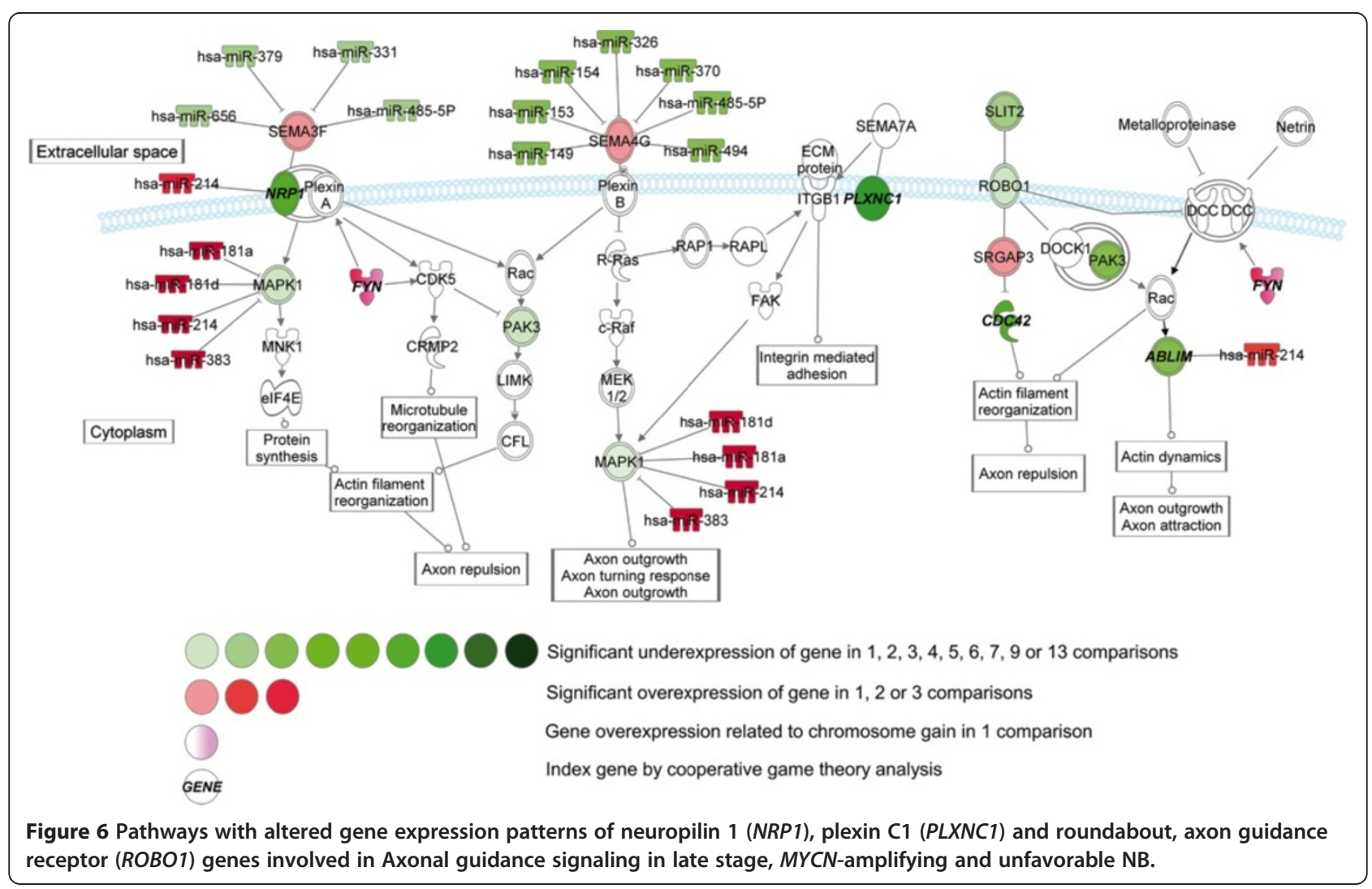




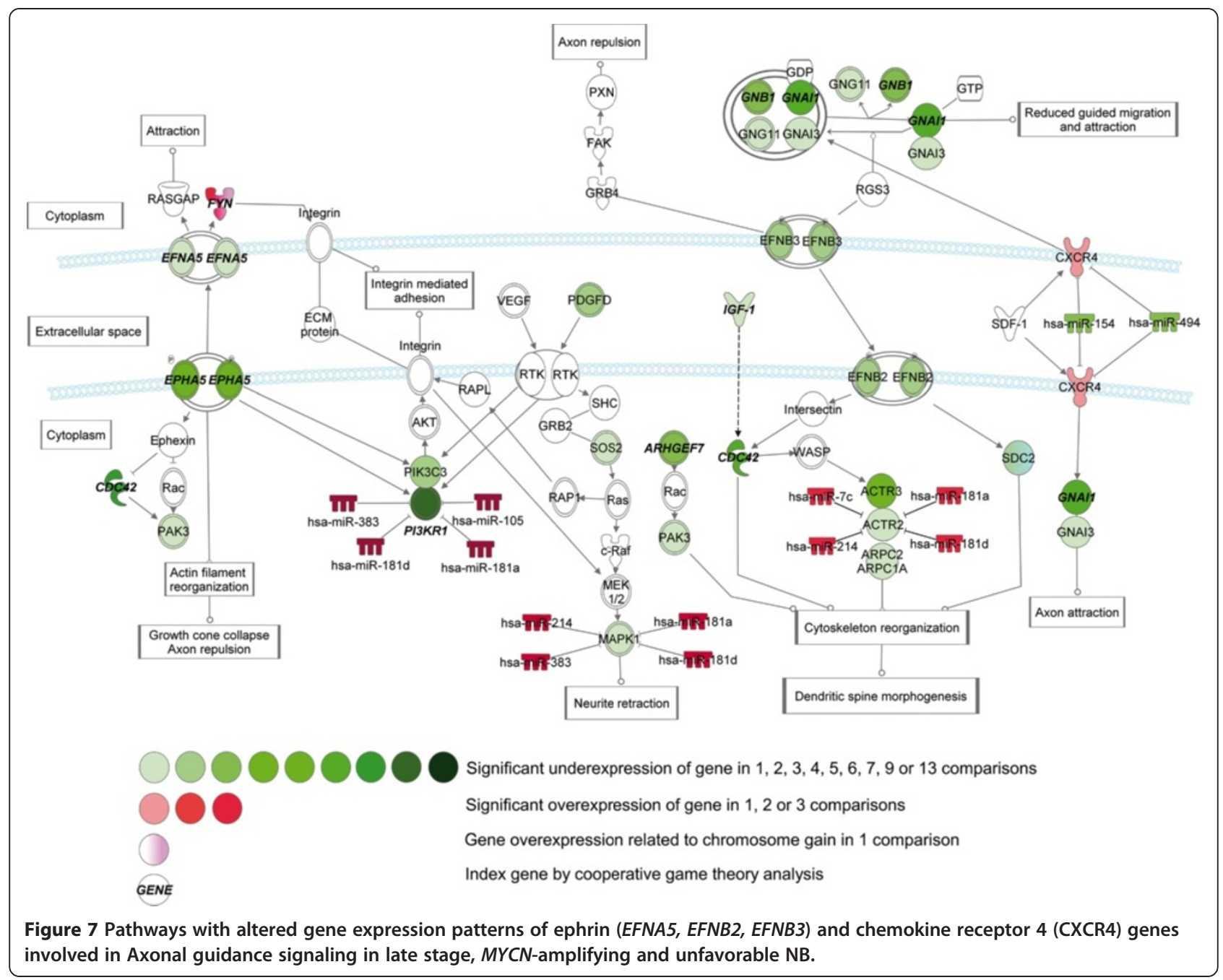

receptor characterized as a tumor suppressor in melanoma [68] was observed in late stage and $M Y C N$-amplifying NB in seven cases (Figure 6). The underexpression of EFNB2 and EFNB3 was observed in two, and the underexpression of ephrin receptor A5 (EPHA5) in five datasets between early and late stage, and $M Y C N$-nonamplifying and amplifying NB, respectively (Figure 7).

Neurophilin-1 (NRP1) receptor is involved in neuronal development and angiogenesis; and it binds semphorin3 proteins and VEGF. Significant downregulation of NRP1 in late stage and $M Y C N$-amplifying NB was noted in five datasets, and downregulation of NRP1 in these cases was correlated with the overexpression of $h s a-m i R-214$ (Figure 6).

In our in silico analysis, we have observed several novel gene expression changes. The expressional alterations of axonal guidance pathway may be important in the development of NB metastases via the disintegration of cell-cell connections and highlight some potential therapeutic targets in unfavorable cases.
Differences between SDH/VHL-, MEN2/NF1-related PCC By the comparison of SDH/VHL- and MEN2/NF1related $\mathrm{PCC}$, representing the two major pathogenic pathways of $\mathrm{PCC}$, the overexpression of genes involved in IGF1 signaling in MEN2/NF1-related tumors has turned out as the most significant pathway (Figure 8). IGF1 promotes cell proliferation, growth and survival in several tissues. Seven binding proteins (IGFBP1-7) are involved in the control of its activity [69]. CYR61 (cysteine-rich, angiogenic inducer, 61), a secreted protein involved in the regulation of angiogenesis is also able to bind IGF1 with low affinity [70].

The IGF1 receptor (IGF1R) is a transmembrane tyrosine kinase protein. The activated IGF1R phosphorylates SHC, which binds to RET and growth factor receptorbound protein 2 (GRB2), leading to activation of RASMAPK signaling. Previous studies confirmed that SHC binding to RET is crucial for the transforming activity of RET mutant proteins [71]. The enhanced IGF-1 signaling in RET-related PCC may be an important parallel 


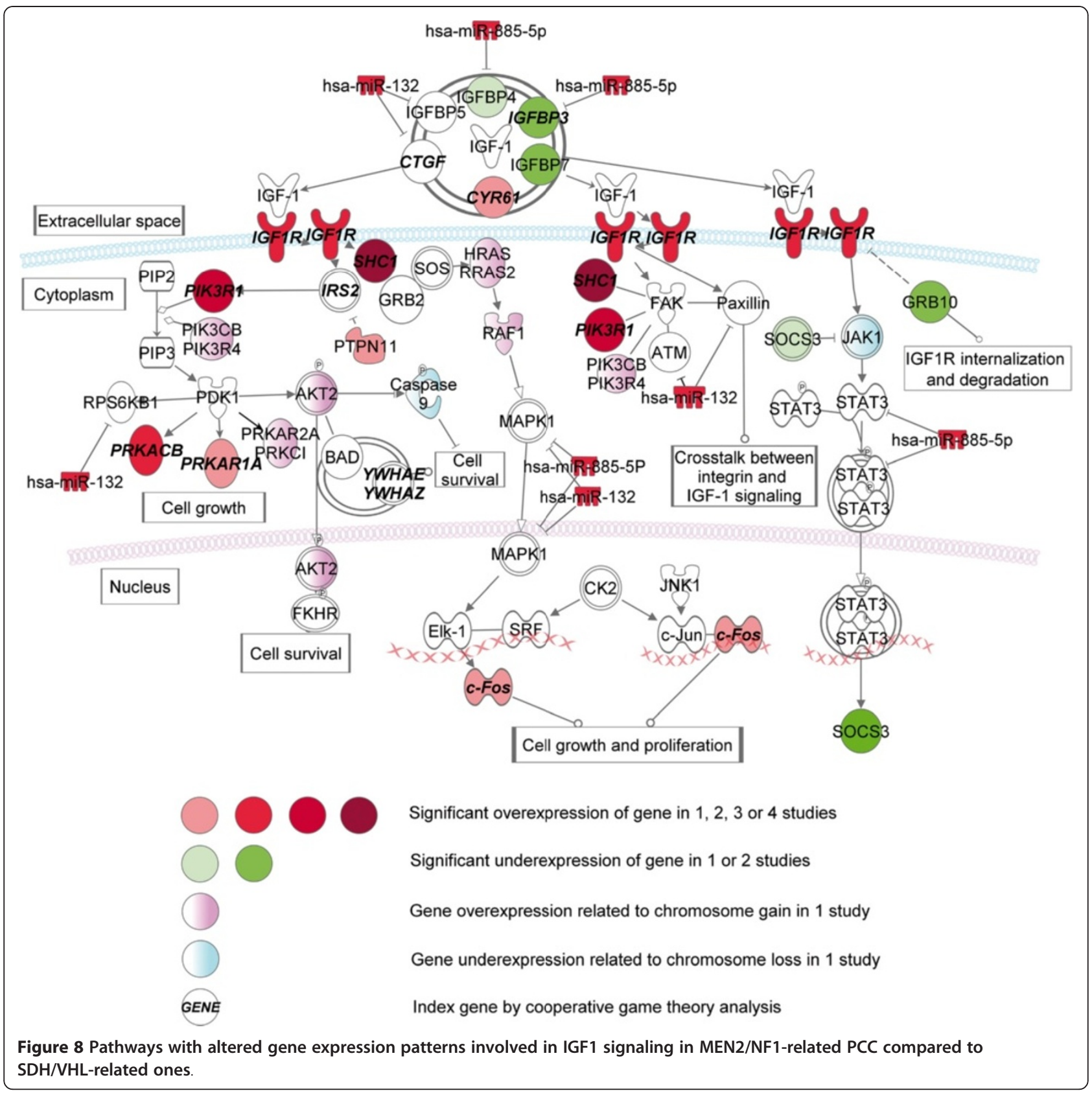

pathway in the pathogenesis, which leads to the activation of RET via SHC. In MEN2/NF1-related PCC, downregulation of $I G F B P 3$ and $I G F B P 7$ was observed in two studies and the downregulation of IGFBP4 and IGFBP5 was correlated with the overexpression of $h s a-m i R-132$ and has-miR-885-5p. The overexpression of IFG1R in MEN2/NF1-related PCC was observed in two studies.

The overexpression of SHC1 and RET was observed in all four comparisons in MEN2/NF1-related PCC. We have also observed the overexpression of $C-F O S$ in these tumors as a possible outcome of the enhanced signaling activities of SHC/GRB/RAS complexes. Furthermore, the overexpression of $H R A S$ and RRAS2 was correlated with the frequent loss of chromosome region $11 \mathrm{p} 15$ in VHL PCC [72].

\section{Differences between MEN2A- and VHL -related PCC}

The comparison of MEN2A- and VHL- related PCC showed the significance of VEGF and HIF1- $\alpha$ signaling. As these pathways overlap at several points, we discuss them together (Figure 9).

HIF1- $\alpha$ is a transcription factor that transactivates genes participating in responses to hypoxia [73]. VHL is involved in the degradation of HIF1- $\alpha$ protein. Under 


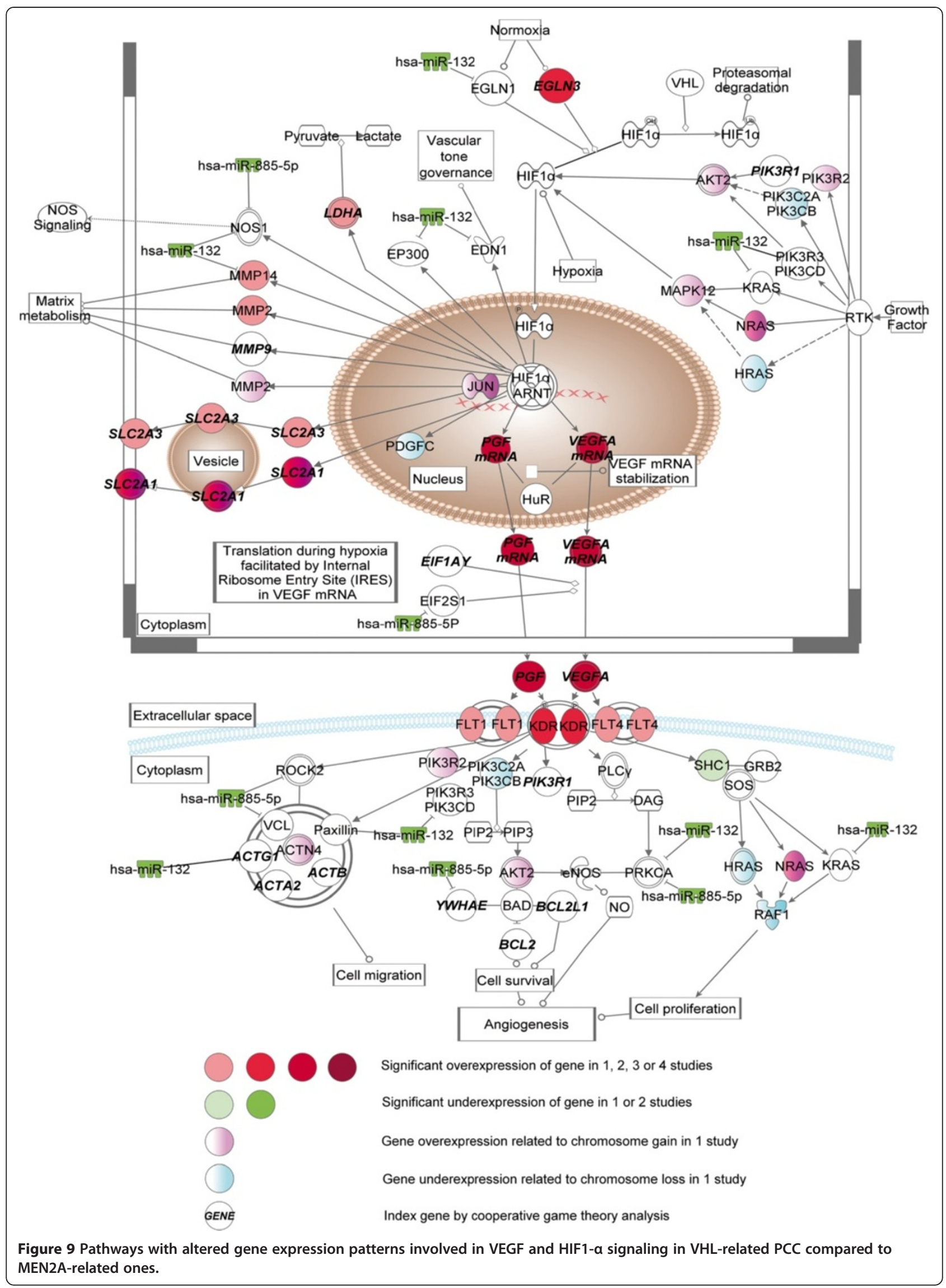


normoxia, EGL nine homolog (EGLN) proteins are activated and hydroxylate HIF1- $\alpha$, which allows VHL protein to bind and ubiquitinate HIF.

By the comparison of MEN2A- and VHL-related PCC, we have observed the significant overexpression of EGLN3 in two studies and the overexpression of EGLN1 was correlated with the downregulation of hsa-miR-132 in VHL PCC. These gene expression changes may lead to enhanced hydroxylation of HIF1- $\alpha$. The overexpression of HIF1- $\alpha$ target genes was also observed in VHL PCC as matrix metalloproteinase $2(M M P 2)$ and glucose transporter GLUT1. GLUT1 overexpression in VHL could be correlated with the frequent loss of chromosome 1p34 often observed in MEN2A PCC [74]. Immunohistochemical analysis of GLUT1, however, failed to detect the protein in chromaffin cells [75]. The overexpression of $M M P 2$ was reported previously in several cancer tissues, and the inhibition of MMP2 function by halofuginone resulted in significant reduction of vascular functionality, decreased vascular density and less tumor size in VHL PCC in vivo models [76].

The overexpression of two VEGF genes, VEGFA and placental growth factor $(P G F)$ were observed in three independent studies in VHL-related PCC. Overexpression of $P G F$ was observed in several cancers. Reduced vascularisation and size of tumors were observed in PGF deficient mice [77]; however, its effect on tumor growth and angiogenesis is controversial. Binding of PGF to VEGFR1 leads to crosstalk between VEGFR1 and VEGFR2 and enhances VEGF-driven VEGFR2 signaling. PGF forms heterodimers with VEGF that do not display significant angiogenic effects, reducing the formation of VEGFVEGF homodimers and lacks the ability of to induce angiogenesis by VEGFR2 activation [78].

The significance of HIF1- $\alpha$ and VEGF signaling is well characterized in VHL PCC, and our results may support and supplement these previous findings. Furthermore, these data corroborate the significance and authenticity of our in silico analysis results.

\section{Conclusions}

The integration of different data sources from the same entities is one of the greatest challenges in contemporary molecular biology. We have applied several bioinformatics approaches to compare and integrate the genetic and transcriptional data from NB and PCC. We have demonstrated the usefulness of reference gene analysis for the identification of similarities among different entities and cooperative game theory analysis as a good method for the supplementation of results by conventional statistical analysis. By the application of these techniques we have performed a complex, integrative analysis which revealed several new pathogenic pathways. Our study has revealed several potential novel genes and pathways that might have major roles in NB and PCC pathogenesis and progression. The role of Stathmin 1 signaling in the pathogenesis of NB and PCC requires experimental validation to characterize its importance in these tumors. The relevance of $P H O X 2 B$ gene and protein has not been studied in the pathogenesis of PCC yet, despite having fundamental role in the neural crest-derived precursor cell development. IGF1 signaling in MEN2/NF1related PCC would also be an interesting topic to investigate. These pathways might even include potential novel therapeutic targets.

\section{Additional files}

Additional file 1: Significantly enriched pathways of the Ingenuity Pathway Analysis in different comparisons. Ratio is calculated as follows: number of significanty differentially expressed genes in a given pathway, divided by total number of genes that make up that pathway.

Additional file 2: Significant gene expression changes between NB or PCC and other normal tissues and tumors (positive fold change values are marking the up-, negatives the downregulated genes in NB or PCC). Genes are ranked by the number of significant expression changes between NB or PCC and other normal tissues and tumors.

Additional file 3: Similar gene expressions among NB and PCC. Genes are ranked by their incidence in the different studies.

Additional file 4: Common gene expression changes between NB and PCC (positive fold change values mark the up-, negatives the downregulated genes in PCC). Genes are ranked by the incidence of significant expression changes among the different studies.

Additional file 5: Common gene expression changes between different subgroups of NB (positive fold change values mark the up-, negatives the downregulated genes in late stage, MYCNamplified or unfavorable NB). Genes are ranked by the incidence of significant expression changes among the different studies.

Additional file 6: Common gene expression changes between SDH/ VHL- and RET/NF1-related PCC (positive fold change values mark the up-, negatives the downregulated genes in RET/NF1-related PCC). Genes are ranked by the incidence of significant expression changes among the different studies.

Additional file 7: Common gene expression changes between MEN2A- and VHL-related PCC (positive fold change values mark the up-, negatives the downregulated genes in VHL-related PCC). Genes are ranked by the incidence of significant expression changes among the different studies.

\section{Competing interests}

The authors declare no conflict of interest.

\section{Authors' contributions}

PMS and PI designed research. PMS, MP, DRS, AZ, AP performed data analysis. PMS, AF, KR and PI wrote the paper. All authors read and approved the final manuscript.

\section{Acknowledgements}

This work was supported by the Hungarian Scientific Research Fund (OTKA K100295) and Foundation for Tumorous Children. Miklós Pintér acknowledges the support by the János Bolyai Research Scholarship of the Hungarian Academy of Sciences and grant OTKA.

\section{Author details}

'2nd Department of Medicine, Faculty of Medicine, Semmelweis University, Szentkirályi str. 46, Budapest H-1088, Hungary. ${ }^{2}$ Department of Mathematics, Corvinus University of Budapest, Fővám sqr. 8, Budapest H-1093, Hungary.

${ }^{3}$ Molecular Medicine Research Group, Hungarian Academy of Sciences, 
Szentkirályi str. 46, Budapest H-1088, Hungary. ${ }^{4}$ Department of Genetics, Celland Immunobiology, Semmelweis University, Nagyvárad sqr. 4, Budapest H-1089, Hungary.

Received: 8 March 2012 Accepted: 26 October 2012

Published: 29 October 2012

\section{References}

1. Maris JM, Hogarty MD, Bagatell R, Cohn SL: Neuroblastoma. Lancet 2007, 369:2106-2120.

2. Mannelli M, Simi L, Gaglianò MS, Opocher G, Ercolino T, Becherini L, Parenti G: Genetics and biology of pheochromocytoma. Exp Clin Endocrinol Diabetes 2007, 115:160-165.

3. Neumann HP, Vortmeyer A, Schmidt D, Werner M, Erlic Z, Cascon A, Bausch B, Januszewicz A, Eng C: Evidence of MEN-2 in the original description of classic pheochromocytoma. N Engl J Med 2007, 357:1311-1315.

4. Comino-Méndez I, Gracia-Aznárez FJ, Schiavi F, Landa I, Leandro-García LJ, Letón R, Honrado E, Ramos-Medina R, Caronia D, Pita G, Gómez-Graña A, de Cubas AA, Inglada-Pérez L, Maliszewska A, Taschin E, Bobisse S, Pica G, Loli P, Hernández-Lavado R, Díaz JA, Gómez-Morales M, González-Neira A, Roncador G, Rodríguez-Antona C, Benítez J, Mannelli M, Opocher G, Robledo M, Cascón A: Exome sequencing identifies MAX mutations as a cause of hereditary pheochromocytoma. Nat Genet 2011, 43:663-667.

5. Qin Y, Yao L, King EE, Buddavarapu K, Lenci RE, Chocron ES, Lechleiter JD, Sass M, Aronin N, Schiavi F, Boaretto F, Opocher G, Toledo RA, Toledo SP, Stiles C, Aguiar RC, Dahia PL: Germline mutations in TMEM127 confer susceptibility to pheochromocytoma. Nat Genet 2010, 42:229-233.

6. Burnichon N, Vescovo L, Amar L, Libé R, de Reynies A, Venisse A, Jouanno E, Laurendeau I, Parfait B, Bertherat J, Plouin PF, Jeunemaitre X, Favier J, Gimenez-Roqueplo AP: Integrative genomic analysis reveals somatic mutations in pheochromocytoma and paraganglioma. Hum Mol Genet 2011, 20:3974-3985.

7. Szabó PM, Tamási V, Molnár V, Andrásfalvy M, Tömböl Z, Farkas R, Kövesdi K, Patócs A, Tóth M, Szalai C, Falus A, Rácz K, Igaz P: Meta-analysis of adrenocortical tumour genomics data: novel pathogenic pathways revealed. Oncogene 2010, 29:3163-3172.

8. Moretti S, Patrone F, Bonassi S: The class of microarray games and the relevance index for genes. Top 2007, 15:256-280.

9. Wang Q, Diskin S, Rappaport E, Attiyeh E, Mosse Y, Shue D, Seiser E, Jagannathan J, Shusterman S, Bansal M, Khazi D, Winter C, Okawa E, Grant G, Cnaan A, Zhao H, Cheung NK, Gerald W, London W, Matthay KK, Brodeur GM, Maris JM: Integrative genomics identifies distinct molecular classes of neuroblastoma and shows that multiple genes are targeted by regional alterations in DNA copy number. Cancer Res 2006, 66:6050-6062.

10. Wilzén A, Nilsson S, Sjöberg RM, Kogner P, Martinsson T, Abel F: The Phox2 pathway is differentially expressed in neuroblastoma tumors, but no mutations were found in the candidate tumor suppressor gene PHOX2A. Int J Oncol 2009, 34:697-705.

11. Albino D, Scaruffi P, Moretti S, Coco S, Truini M, Di Cristofano C, Cavazzana A, Stigliani S, Bonassi S, Tonini GP: Identification of low intratumoral gene expression heterogeneity in neuroblastic tumors by genome-wide expression analysis and game theory. Cancer 2008, 113:1412-1422.

12. De Preter K, Vandesompele J, Heimann P, Yigit N, Beckman S, Schramm A, Eggert A, Stallings RL, Benoit Y, Renard M, De Paepe A, Laureys G, Påhlman $S$, Speleman F: Human fetal neuroblast and neuroblastoma transcriptome analysis confirms neuroblast origin and highlights neuroblastoma candidate genes. Genome Biol 2006, 7:R84.

13. Hiyama E, Hiyama K, Yamaoka H, Sueda T, Reynolds CP, Yokoyama T: Expression profiling of favorable and unfavorable neuroblastomas. Pediatr Surg Int 2004, 20:33-38.

14. Janoueix-Lerosey I, Lequin D, Brugières L, Ribeiro A, de Pontual L, Combaret V, Raynal V, Puisieux A, Schleiermacher G, Pierron G, Valteau-Couanet D, Frebourg T, Michon J, Lyonnet S, Amiel J, Delattre O: Somatic and germline activating mutations of the ALK kinase receptor in neuroblastoma. Nature 2008, 455:967-970.

15. Łastowska M, Viprey V, Santibanez-Koref M, Wappler I, Peters H, Cullinane C, Roberts P, Hall AG, Tweddle DA, Pearson AD, Lewis I, Burchill SA, Jackson MS: Identification of candidate genes involved in neuroblastoma progression by combining genomic and expression microarrays with survival data. Oncogene 2007, 26:7432-7444.
16. Staege MS, Hutter C, Neumann I, Foja S, Hattenhorst UE, Hansen G, Afar D, Burdach SE: DNA microarrays reveal relationship of Ewing family tumors to both endothelial and fetal neural crest-derived cells and define novel targets. Cancer Res 2004, 64:8213-8221.

17. Hensen EF, Goeman JJ, Oosting J, Van der Mey AG, Hogendoorn PC, Cremers CW, Devilee P, Cornelisse CJ: Similar gene expression profiles of sporadic, PGL2-, and SDHD-linked paragangliomas suggest a common pathway to tumorigenesis. BMC Med Genomics 2009, 2:25.

18. Boyault $S$, Rickman DS, de Reyniès A, Balabaud $C$, Rebouissou $S$, Jeannot $E$, Hérault A, Saric J, Belghiti J, Franco D, Bioulac-Sage P, Laurent-Puig P, Zucman-Rossi J: Transcriptome classification of HCC is related to gene alterations and to new therapeutic targets. Hepatology 2007, 45:42-52.

19. Corbin $M$, de Reyniès $A$, Rickman DS, Berrebi D, Boccon-Gibod L, Cohen-Gogo S, Fabre M, Jaubert F, Faussillon M, Yilmaz F, Sarnacki S, Landman-Parker J, Patte C, Schleiermacher G, Antignac C, Jeanpierre C: WNT/beta-catenin pathway activation in Wilms tumors: a unifying mechanism with multiple entries? Genes Chromosomes Cancer 2009, 48:816-827.

20. Freije WA, Castro-Vargas FE, Fang Z, Horvath S, Cloughesy T, Liau LM, Mischel PS, Nelson SF: Gene expression profiling of gliomas strongly redicts survival. Cancer Res 2004, 64:6503-6510.

21. Giordano TJ, Au AY, Kuick R, Thomas DG, Rhodes DR, Wilhelm KG Jr, Vinco M, Misek DE, Sanders D, Zhu Z, Ciampi R, Hanash S, Chinnaiyan A, CliftonBligh RJ, Robinson BG, Nikiforov YE, Koenig RJ: Delineation, functional validation, and bioinformatic evaluation of gene expression in thyroid follicular carcinomas with the PAX8-PPARG translocation. Clin Cancer Res 2006, 12:1983-1993.

22. Harlin H, Meng Y, Peterson AC, Zha Y, Tretiakova M, Slingluff C, McKee M, Gajewski TF: Chemokine expression in melanoma metastases associated with CD8+ T-cell recruitment. Cancer Res 2009, 69:3077-3085.

23. Henderson SR, Guiliano D, Presneau N, McLean S, Frow R, Vujovic S, Anderson J, Sebire N, Whelan J, Athanasou N, Flanagan AM, Boshoff C: A molecular map of mesenchymal tumors. Genome Biol 2005, 6:R76.

24. Jones J, Otu H, Spentzos D, Kolia S, Inan M, Beecken WD, Fellbaum C, Gu X, Joseph M, Pantuck AJ, Jonas D, Libermann TA: Gene signatures of progression and metastasis in renal cell cancer. Clin Cancer Res 2005, 11:5730-5739.

25. Lenburg ME, Liou LS, Gerry NP, Frampton GM, Cohen HT, Christman MF: Previously unidentified changes in renal cell carcinoma gene expression identified by parametric analysis of microarray data. BMC Cancer 2003, 3:31.

26. Monzon FA, Lyons-Weiler M, Buturovic LJ, Rigl CT, Henner WD, Sciulli C, Dumur Cl, Medeiros F, Anderson GG: Multicenter validation of a 1,550gene expression profile for identification of tumor tissue of origin. J Clin Oncol 2009, 27:2503-2508.

27. Parent AS, Matagne V, Westphal M, Heger S, Ojeda S, Jung H: Gene expression profiling of hypothalamic hamartomas: a search for genes associated with central precocious puberty. Horm Res 2008, 69:114-123.

28. Su LJ, Chang CW, Wu YC, Chen KC, Lin CJ, Liang SC, Lin CH, Whang-Peng J, Hsu SL, Chen CH, Huang CY: Selection of DDX5 as a novel internal control for Q-RT-PCR from microarray data using a block bootstrap re-sampling scheme. BMC Genomics 2007, 8:140.

29. Tirode F, Laud-Duval K, Prieur A, Delorme B, Charbord P, Delattre O: Mesenchymal stem cell features of Ewing tumors. Cancer Cell 2007, 11:421-429.

30. Wong KK, Chang YM, Tsang YT, Perlaky L, Su J, Adesina A, Armstrong DL, Bhattacharjee M, Dauser R, Blaney SM, Chintagumpala M, Lau CC: Expression analysis of juvenile pilocytic astrocytomas by oligonucleotide microarray reveals two potential subgroups. Cancer Res 2005, 65:76-84.

31. Schramm A, Schulte JH, Klein-Hitpass L, Havers W, Sieverts H, Berwanger B, Christiansen $\mathrm{H}$, Warnat P, Brors B, Eils J, Eils R, Eggert A: Prediction of clinical outcome and biological characterization of neuroblastoma by expression profiling. Oncogene 2005, 24:7902-7912.

32. López-Jiménez E, Gómez-López G, Leandro-García LJ, Muñoz I, Schiavi F, Montero-Conde C, de Cubas AA, Ramires R, Landa I, Leskelä S, Maliszewska A, Inglada-Pérez L, de la Vega L, Rodríguez-Antona C, Letón R, Bernal C, de Campos JM, Diez-Tascón C, Fraga MF, Boullosa C, Pisano DG, Opocher G, Robledo M, Cascón A: Research resource: transcriptional profiling reveals different pseudohypoxic signatures in SDHB and VHL-related pheochromocytomas. Mol Endocrinol 2010, 24:2382-2391. 
33. Oberthuer A, Warnat $P$, Kahlert $Y$, Westermann F, Spitz R, Brors B, Hero B, Eils $R$, Schwab M, Berthold F, Fischer M: Classification of neuroblastoma patients by published gene-expression markers reveals a low sensitivity for unfavorable courses of MYCN non-amplified disease. Cancer Lett 2007, 250:250-267.

34. Ohira M, Oba S, Nakamura Y, Isogai E, Kaneko S, Nakagawa A, Hirata T, Kubo H, Goto T, Yamada S, Yoshida Y, Fuchioka M, Ishii S, Nakagawara A: Expression profiling using a tumour-specific cDNA microarray predicts the prognosis of intermediate risk neuroblastomas. Cancer Cell 2005, 7:337-350.

35. Asgharzadeh S, Pique-Regi R, Sposto R, Wang $H$, Yang $Y$, Shimada $H$, Matthay K, Buckley J, Ortega A, Seeger RC: Prognostic significance of gene expression profiles of metastatic neuroblastomas lacking MYCN gene amplification. J Natl Cancer Inst 2006, 98:1193-1203.

36. Berwanger B, Hartmann O, Bergmann E, Bernard S, Nielsen D, Krause M, Kartal A, Flynn D, Wiedemeyer R, Schwab M, Schäfer H, Christiansen H, Eilers M: Loss of a FYN-regulated differentiation and growth arrest pathway in advanced stage neuroblastoma. Cancer Cell 2002, 2:377-386.

37. Brown JL, Snir M, Noushmehr H, Kirby M, Hong SK, Elkahloun AG, Feldman B: Transcriptional profiling of endogenous germ layer precursor cells identifies dusp4 as an essential gene in zebrafish endoderm specification. Proc Natl Acad Sci USA 2008, 105:2337-2342.

38. Eisenhofer G, Huynh TT, Pacak K, Brouwers FM, Walther MM, Linehan WM, Munson PJ, Mannelli M, Goldstein DS, Elkahloun AG: Distinct gene expression profiles in norepinephrine- and epinephrine-producing hereditary and sporadic pheochromocytomas: activation of hypoxiadriven angiogenic pathways in von Hippel-Lindau syndrome. Endocr Relat Cancer 2004, 11:897-911.

39. Eisenhofer G, Huynh TT, Elkahloun A, Morris JC, Bratslavsky G, Linehan WM, Zhuang Z, Balgley BM, Lee CS, Mannelli M, Lenders JW, Bornstein SR, Pacak $\mathrm{K}$ : Differential expression of the regulated catecholamine secretory pathway in different hereditary forms of pheochromocytoma. Am J Physiol Endocrinol Metab 2008, 295:E1223-E1233.

40. Fischer M, Bauer T, Oberthür A, Hero B, Theissen J, Ehrich M, Spitz R, Eils R, Westermann F, Brors B, König R, Berthold F: Integrated genomic profiling identifies two distinct molecular subtypes with divergent outcome in neuroblastoma with loss of chromosome 11q. Oncogene 2010, 29:865-875.

41. Huynh TT, Pacak K, Wong DL, Linehan WM, Goldstein DS, Elkahloun AG, Munson PJ, Eisenhofer G: Transcriptional regulation of phenylethanolamine N-methyltransferase in pheochromocytomas from patients with von Hippel-Lindau syndrome and multiple endocrine neoplasia type 2. Ann N Y Acad Sci 2006, 1073:241-252.

42. Oberthuer A, Berthold F, Warnat $P$, Hero B, Kahlert $Y$, Spitz R, Ernestus $K$, König R, Haas S, Eils R, Schwab M, Brors B, Westermann F, Fischer M: Customized oligonucleotide microarray gene expression-based classification of neuroblastoma patients outperforms current clinical risk stratification. J Clin Oncol 2006, 24:5070-5078.

43. Takita J, Ishii M, Tsutsumi S, Tanaka Y, Kato K, Toyoda Y, Hanada R, Yamamoto K, Hayashi Y, Aburatani H: Gene expression profiling and identification of novel prognostic marker genes in neuroblastoma. Genes Chromosomes Cancer 2004, 40:120-132.

44. Thorell K, Bergman A, Carén H, Nilsson S, Kogner P, Martinsson T, Abel F: Verification of genes differentially expressed in neuroblastoma tumours: a study of potential tumour suppressor genes. BMC Med Genomics 2009, 2:53.

45. Vermeulen J, De Preter K, Naranjo A, Vercruysse L, Van Roy N, Hellemans J, Swerts K, Bravo S, Scaruffi P, Tonini GP, De Bernardi B, Noguera R, Piqueras M, Cañete A, Castel V, Janoueix-Lerosey I, Delattre O, Schleiermacher G, Michon J, Combaret V, Fischer M, Oberthuer A, Ambros PF, Beiske K, Bénard J, Marques B, Rubie H, Kohler J, Pötschger U, Ladenstein R, Hogarty MD, McGrady P, London WB, Laureys G, Speleman F, Vandesompele J: Predicting outcomes for children with neuroblastoma using a multigene-expression signature: a retrospective SIOPEN/COG/GPOH study. Lancet Oncol 2009, 10:663-671.

46. Schulte $\mathrm{HH}$, Schowe B, Mestdagh P, Kaderali L, Kalaghatgi P, Schlierf S, Vermeulen J, Brockmeyer B, Pajtler K, Thor T, de Preter K, Speleman F, Morik K, Eggert A, Vandesompele J, Schramm A: Accurate prediction of neuroblastoma outcome based on miRNA expression profiles. Int $J$ Cancer 2010, 127:2374-2385.
47. Tömböl Z, Eder K, Kovács A, Szabó PM, Kulka J, Likó I, Zalatnai A, Rácz G, Tóth M, Patócs A, Falus A, Rácz K, Igaz P: MicroRNA expression profiling in benign (sporadic and hereditary) and recurring adrenal pheochromocytomas. Mod Pathol 2010, 23:1583-1595.

48. Cheng WC, Chang CW, Chen CR, Tsai ML, Shu WY, Li CY, Hsu IC: Identification of reference genes across physiological states for qRT-PCR through microarray meta-analysis. PLoS One 2011, 6:e17347.

49. Shapley LS: A Value for n-Person Games. In Contributions to the Theory of Games Volume II (Annals of Mathematical Studies 28). Edited by Kuhn HW, Tucker AW. Princeton: Princeton University Press; 1953:307-317.

50. Subramanian A, Tamayo P, Mootha VK, Mukherjee S, Ebert BL, Gillette MA, Paulovich A, Pomeroy SL, Golub TR, Lander ES, Mesirov JP: Gene set enrichment analysis: a knowledge-based approach for interpreting genome-wide expression profiles. Proc Natl Acad Sci USA 2005, 102:15545-15550.

51. Martini P, Risso D, Sales G, Romualdi C, Lanfranchi G, Cagnin S: Statistical Test of Expression Pattern (STEPath): a new strategy to integrate gene expression data with genomic information in individual and metaanalysis studies. BMC Bioinformatics 2011, 12:92.

52. Tömböl Z, Szabó PM, Molnár V, Wiener Z, Tölgyesi G, Horányi J, Riesz P, Reismann P, Patócs A, Likó I, Gaillard RC, Falus A, Rácz K, Igaz P: Integrative molecular bioinformatics study of human adrenocortical tumors: microRNA, tissue-specific target prediction, and pathway analysis. Endocr Relat Cancer 2009, 16:895-906.

53. Huber K, Karch N, Ernsberger U, Goridis C, Unsicker K: The role of Phox2B in chromaffin cell development. Dev Biol 2005, 279:501-508.

54. Mosse YP, Laudenslager M, Khazi D, Carlisle AJ, Winter CL, Rappaport E, Maris JM: Germline PHOX2B mutation in hereditary neuroblastoma. Am J Hum Genet 2004, 75:727-730.

55. Zhu J, Garcia-Barcelo MM, Tam PK, Lui VC: HOXB5 cooperates with NKX2-1 in the transcription of human RET. PLOS One 2011, 6:e20815.

56. Rychlik J, Hsieh M, Eiden LE, Lewis EJ: Phox2 and dHAND transcription factors select shared and unique target genes in the noradrenergic cell type. J Mol Neurosci 2005, 27:281-292.

57. Margetts CD, Astuti D, Gentle DC, Cooper WN, Cascon A, Catchpoole D, Robledo M, Neumann HP, Latif F, Maher ER: Epigenetic analysis of HIC1, CASP8, FLIP, TSP1, DCR1, DCR2, DR4, DR5, KvDMR1, H19 and preferential 11 p15.5 maternal-allele loss in von Hippel-Lindau and sporadic phaeochromocytomas. Endocr Relat Cancer 2005, 12:161-172.

58. Poulaki V, Mitsiades N, Romero ME, Tsokos M: Fas-mediated apoptosis in neuroblastoma requires mitochondrial activation and is inhibited by FLICE inhibitor protein and Bcl-2. Cancer Res 2001, 61:4864-4872.

59. Mah SP, Zhong LT, Liu Y, Roghani A, Edwards RH, Bredesen DE: The protooncogene bcl-2 inhibits apoptosis in PC12 cells. J Neurochem 1993, 60:1183-1186

60. Okawa ER, Gotoh T, Manne J, Igarashi J, Fujita T, Silverman KA, Xhao H, Mosse YP, White PS, Brodeur GM: Expression and sequence analysis of candidates for the $1 \mathrm{p} 36.31$ tumor suppressor gene deleted in neuroblastomas. Oncogene 2008, 27:803-810.

61. Aarts M, Dannenberg H, DeLeeuw RJ, van Nederveen FH, Verhofstad AA, Lenders JW, Dinjens WN, Speel EJ, Lam WL, de Krijger RR: Microarray-based CGH of sporadic and syndrome-related pheochromocytomas using a 0.1-0.2 Mb bacterial artificial chromosome array spanning chromosome arm 1p. Genes Chromosomes Cancer 2006, 45:83-93.

62. Björklund $P$, Cupisti $K$, Fryknäs M, Isaksson A, Willenberg HS, Akerström G, Hellman P, Westin G: Stathmin as a marker for malignancy in pheochromocytomas. Exp Clin Endocrinol Diabetes 2010, 118:27-30.

63. Sadow PM, Rumilla KM, Erickson LA, Lloyd RV: Stathmin expression in pheochromocytomas, paragangliomas, and in other endocrine tumors. Endocr Pathol 2008, 19:97-103.

64. Cassimeris $\mathrm{L}$ : The oncoprotein 18 /stathmin family of microtubule destabilizers. Curr Opin Cell Biol 2002, 14:18-24.

65. Don S, Verrills NM, Liaw TY, Liu ML, Norris MD, Haber M, Kavallaris M: Neuronal-associated microtubule proteins class III beta-tubulin and MAP2c in neuroblastoma: role in resistance to microtubule-targeted drugs. Mol Cancer Ther 2004, 3:1137-1146.

66. Bashaw GJ, Klein R: Signaling from axon guidance receptors. Cold Spring Harb Perspect Biol 2010, 2:a001941.

67. Brodeur GM, Minturn JE, Ho R, Simpson AM, lyer R, Varela CR, Light JE, Kolla $\checkmark$, Evans AE: Trk receptor expression and inhibition in neuroblastomas. Clin Cancer Res 2009, 15:3244-3250. 
68. Lazova R, Gould Rothberg BE, Rimm D, Scott G: The semaphorin 7A receptor Plexin $\mathrm{C} 1$ is lost during melanoma metastasis. Am J Dermatopathol 2009, 31:177-181.

69. Grimberg A, Cohen P: Role of insulin-like growth factors and their binding proteins in growth control and carcinogenesis. J Cell Physiol 2000, 183:1-9.

70. Yu Y, Gao Y, Qin J, Kuang CY, Song MB, Yu SY, Cui B, Chen JF, Huang L: CCN1 promotes the differentiation of endothelial progenitor cells and reendothelialization in the early phase after vascular injury. Basic Res Cardiol 2010, 105:713-724

71. Kawai K, Iwashita T, Murakami H, Hiraiwa N, Yoshiki A, Kusakabe M, Ono K, lida K, Nakayama A, Takahashi M: Tissue-specific carcinogenesis in transgenic mice expressing the RET proto-oncogene with a multiple endocrine neoplasia type 2A mutation. Cancer Res 2000, 60:5254-5260.

72. Lui WO, Chen J, Gläsker S, Bender BU, Madura C, Khoo SK, Kort E, Larsson C, Neumann HP, Teh BT: Selective loss of chromosome 11 in pheochromocytomas associated with the VHL syndrome. Oncogene 2002, 21:1117-1122

73. Kaelin WG Jr: Molecular basis of the VHL hereditary cancer syndrome. Nat Rev Cancer 2002, 2:673-682.

74. Van Nederveen FH, Korpershoek E, DeLeeuw RJ, Verhofstad AA, Lenders JW, Dinjens WN, Lam WL, de Krijger RR: Array-comparative genomic hybridization in sporadic benign pheochromocytomas. Endocr Relat Cancer 2009, 16:505-513.

75. Favier J, Brière JJ, Burnichon N, Rivière J, Vescovo L, Benit P, Giscos-Douriez I, De Reyniès A, Bertherat J, Badoual C, Tissier F, Amar L, Libé R, Plouin PF, Jeunemaitre X, Rustin P, Gimenez-Roqueplo AP: The Warburg effect is genetically determined in inherited pheochromocytomas. PLoS One 2009, 4:e7094.

76. Gross DJ, Reibstein I, Weiss L, Slavin S, Dafni H, Neeman M, Pines M, Nagler A: Treatment with halofuginone results in marked growth inhibition of a von Hippel-Lindau pheochromocytoma in vivo. Clin Cancer Res 2003, 9:3788-3793.

77. Carmeliet P, Moons L, Luttun A, Vincenti V, Compernolle V, De Mol M, Wu Y, Bono F, Devy L, Beck H, Scholz D, Acker T, DiPalma T, Dewerchin M, Noel A, Stalmans I, Barra A, Blacher S, Vandendriessche T, Ponten A, Eriksson U, Plate KH, Foidart JM, Schaper W, Charnock-Jones DS, Hicklin DJ, Herbert JM, Collen D, Persico MG: Synergism between vascular endothelial growth factor and placental growth factor contributes to angiogenesis and plasma extravasation in pathological conditions. Nat Med 2001, 7:575-583.

78. Ribatti D: The controversial role of placental growth factor in tumor growth. Cancer Lett 2011, 307:1-5.

doi:10.1186/1755-8794-5-48

Cite this article as: Szabó et al:: Integrative analysis of neuroblastoma and pheochromocytoma genomics data. BMC Medical Genomics 2012 $5: 48$

\section{Submit your next manuscript to BioMed Central and take full advantage of:}

- Convenient online submission

- Thorough peer review

- No space constraints or color figure charges

- Immediate publication on acceptance

- Inclusion in PubMed, CAS, Scopus and Google Scholar

- Research which is freely available for redistribution 